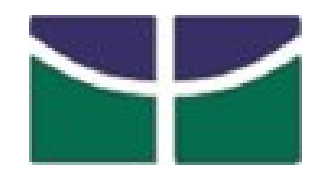

Universidade de Brasília

Centro de Excelência em Turismo

\title{
PROJETO ORLA: PLANEJAMENTO X DEGRADAÇÃO
}

\author{
Luciana da Silva Morais
}

\author{
Rafael Sanzio
}

Monografia apresentada ao Centro de Excelência em Turismo da Universidade de Brasília como requisito parcial para a obtenção do certificado de Especialização em Turismo e Hospitalidade.

Brasília, DF, Fevereiro de 2004. 
UNIVERSIDADE DE BRASÍLIA

Centro de Excelência em Turismo

Curso de Especialização em Formação de Professores em Turismo e Hospitalidade

PROJETO ORLA: PLANEJAMENTO X DEGRADAÇÃO

Luciana da Silva Morais

Banca Examinadora

Nome do Orientador, titulação

Rafael Sanzio

\author{
Nome, titulação \\ Membro da Banca
}

Brasília, DF, 26 de Fevereiro de 2004. 
Morais Silva, Luciana

Projeto Orla: Planejamento X Degradação / Luciana da Silva Morais.

62 f: il.

Monografia (especialização) - Universidade de Brasília. Centro de Excelência em Turismo. Brasília, 2004.

Área de concentração: Turismo

Orientador: Rafael Sanzio.

1. Turismo 2. Turismo Urbano 3. Meio Ambiente - Monografia 
Luciana da Silva Morais

Projeto Orla: Planejamento X Degradação

Comissão Avaliadora

Professor Orientador

Prof. $\mathrm{X}$

Prof. $Y$

Brasília, DF, 26 de Fevereiro de 2004. 
DEDICATÓRIA:

À minha mãe Neuza por seu exemplo de vida, pelo carinho e apoio total dados a minha pessoa, em todos os momentos da minha vida. 


\section{AGRADECIMENTOS:}

Á Deus que sempre esteve iluminando o meu caminho e com seu imenso amor, permitiu a realização deste sonho - concluir com êxito esta Pós-Graduação.

Aos meus pais Valdemar e Neuza que, através do apoio e incentivos materiais, psicológicos e morais, contribuíram para o meu sucesso acadêmico.

Ao meu namorado Marco Pólo que demonstrou amor, companheirismo, paciência, compreensão e apoio para a conquista dos meus objetivos.

Á minha melhor amiga Maria do Carmo e ao meu irmão Lucas que estiveram ao meu lado me apoiando psicologicamente e me incentivando para conquistar o meu sonho.

Aos professores do CET-UnB em especial ao meu orientador Rafael Sanzio. 
"Deste Planalto Central, desta solidão que em breve se transformará em cérebro das altas decisões nacionais, lanço os olhos sobre o amanhã do meu país e antevejo esta alvorada com fé inquebrantável e uma confiança sem limites no seu grande destino."

Juscelino Kubischek 


\section{SUMÁRIO:}

1. INTRODUÇÃO --- 04

2. OBJETIVOS -- 05

3. METODOLOGIA ---- 26

4. AVALIAÇÃO MULTITEMPORAL DA OCUPAÇÃO DO SOLO NA ORLA DO LAGO PARANOÁ ---

$4.11^{\circ}$ TEMPO - MAPA DE USO DO SOLO EM 1954

$4.22^{\circ}$ TEMPO - MAPA DE USO DO SOLO EM 1964 --.-- 08

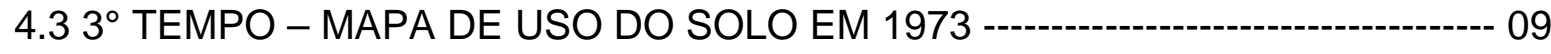

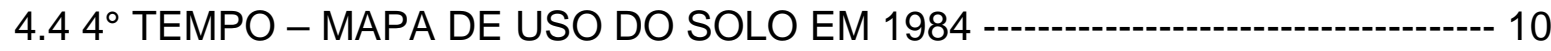

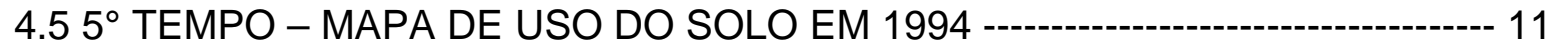

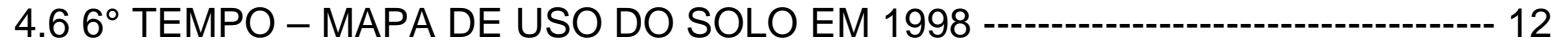

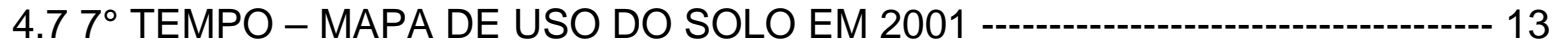

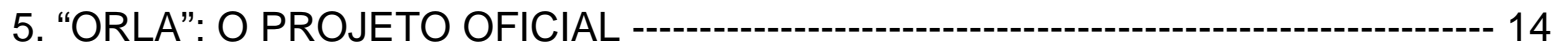

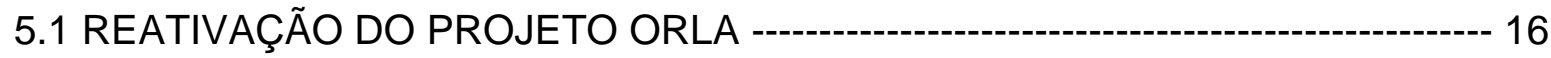

5.2 A PRÓXIMA ETAPA -- 18

6. OCUPAÇÃO TERRITORIAL DA ORLA DO LAGO PARANOÁ ----------------19

6.1 AS PROPRIEDADES QUE FAZEM DIVISA COM O LAGO --.-- 22

6.2 AS PROPRIEDADES QUE INVADEM ÁREA PÚBLICA -------------------------- 24

7. RESULTADO DAS ENTREVISTAS EXECUTADAS ---

8. CONCLUSÃO -

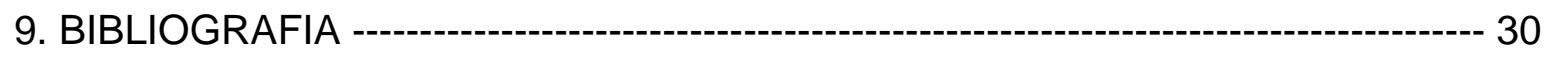


10. ANEXOS:

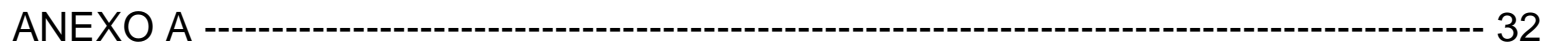

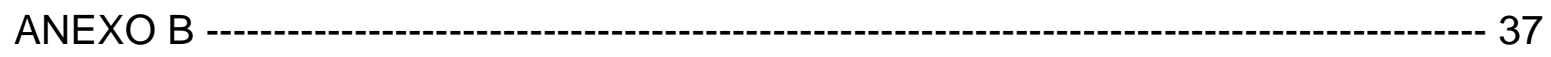

ANEXO C - - 40

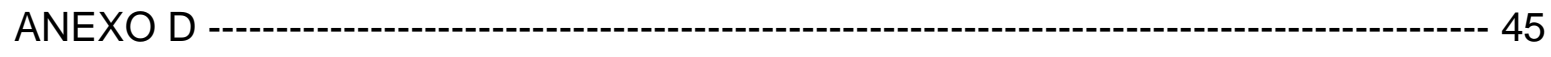

ANEXO E -- 50 


\section{LISTA DE ILUSTRAÇÕES:}

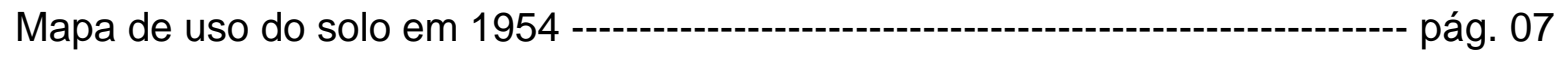

Mapa de uso do solo em 1964 -------------------------------------------------------------- pág. 08

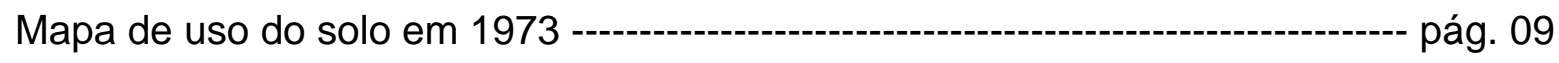

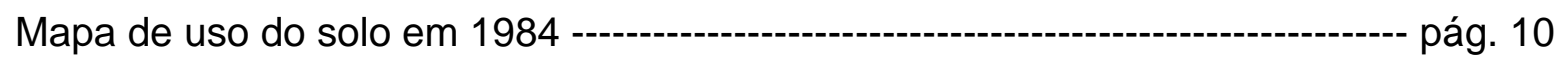

Mapa de uso do solo em 1994 ------------------------------------------------------------- pág. 11

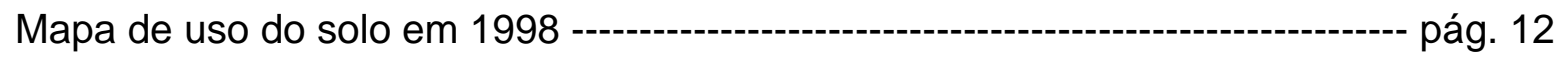

Mapa de uso do solo em 2001 -------------------------------------------------------------- pág. 13 


\section{INTRODUÇÃO:}

A propensão que Brasília tem para a atividade turística é inegável. A cidade apresenta características exclusivas para se desenvolver a partir do turismo. É a Capital Federal, planejada e localizada no centro geográfico do país, Patrimônio Cultural da Humanidade, a representação do moderno para o mundo, com arquitetura inovadora, grandes áreas verdes e um céu magnífico.

O Lago Paranoá que mesmo antes da sua construção já foi destinado por Lúcio Costa para o lazer da população urbana, não sendo permitido inicialmente residências e sim pontos destinados aos diversos tipos de entretenimento é o objeto de estudo desta pesquisa, sendo enfatizado o Projeto Orla e a ocupação territorial da respectiva região.

O Projeto Orla que alertou Brasília para o potencial do Lago Paranoá no que diz respeito às suas aptidões inusitadas para a implementação da atividade turística e de lazer que o lago proporciona, com o objetivo de manter a sua orla pública e destinada à implementação de 11 pólos com empreendimentos diversos para serem explorados comercialmente, ainda se encontra em um ritmo de implantação demorado, apesar da sua recente reativação.

No transcurso deste trabalho foi realizado um levantamento histórico relatando-se através de mapas alguns momentos específicos que evidenciam o Lago Paranoá e a sua orla antes e depois da sua construção, caracterizando-se principalmente a ocupação do seu território nestas ocasiões.

A seguir é relatado sobre o Projeto Orla destacando-se a sua proposta original, a sua situação atual com a reativação do projeto, a reforma da Concha Acústica, a sua realização mais recente e a próxima meta que é altamente dependente da iniciativa privada, assim como todo o projeto, que é a construção e consolidação do Pólo Gastronômico que visa atender aos visitantes e à população local que freqüentam a orla do lago.

O destaque à questão ambiental relacionado à ocupação territorial pelos proprietários de terrenos particulares próximos ao lago foi indispensável. Por um lado de nada adianta se ter todo um projeto turístico, com uma ocupação territorial planejada em diversos espaços destinados ao lazer se por outro as invasões de áreas públicas designadas ao turismo de lazer se tornaram evidentes, acarretando em uma série de impactos ambientais sem que realmente alguma atitude eficaz fosse adotada por parte das autoridades. Assim sendo, esse desordenamento territorial tornou-se uma ameaça a mais à sustentabilidade do lago.

Finalizando apresentam-se fotografias e diversas matérias de jornais locais relacionados à pesquisa realizada, que podem ser verificadas nos anexos. 


\section{OBJETIVOS:}

2.1 - Averiguar o teor do Projeto Orla;

2.2 - Avaliar as construções previstas e realizadas de acordo com o Projeto Orla;

2.3 - Analisar os impactos ambientais relacionados à ocupação territorial no Lago Paranoá. 


\section{METODOLOGIA:}

A metodologia instituída para a efetivação desta monografia foi de cunho qualitativo, com trabalho de campo e ângulo de abordagem social, tendo em vista os objetivos anteriormente determinados.

As entrevistas realizadas não tiveram como base um questionário estruturado, mas um roteiro com os assuntos a serem tratados durante as mesmas de acordo com os seus objetivos. Assim a entrevistadora encaminhou a conversa espontaneamente não estando vinculada a uma série de perguntas pré-formuladas.

Ao mesmo tempo foram efetuadas pesquisas em Bibliotecas, Jornais, Internet - sites das Secretarias do GDF e trabalho de campo nos pontos do Projeto Orla e em torno do Lago Paranoá. Abaixo se apresenta uma relação do que foi efetuado:

$1^{\circ}$ - Consulta a Bibliotecas: UnB e Secretarias a procura de material de apoio à análise;

$2^{\circ}$ - Coleta de dados e leitura bibliográfica sobre ocupação territorial, meio ambiente, sustentabilidade e Projeto Orla;

$3^{\circ}$ - Comparação de diversos mapas de Brasília - multitemporal, físico, político e turístico;

$4^{\circ}$ - Pesquisas na Internet;

$5^{\circ}$ - Visita a clubes da orla e a órgãos governamentais: TERRACAP, ADETUR, SEMARH e Secretaria de Obras;

$6^{\circ}$ - Análise dos locais do Projeto e das construções à margem do Lago Paranoá e $7^{\circ}$ - Registro através de fotografias, para esclarecimento da pesquisa, dos principais pólos do Projeto Orla. 


\section{AVALIAÇÃO MULTITEMPORAL DA OCUPAÇÃO DO SOLO NA ORLA DO LAGO PARANOÁ:}

O Lago Paranoá apresenta características exclusivas que o transforma em um modelo ideal no que tange a relação entre a ocupação territorial do seu espaço geográfico e o turismo.

O lago foi planejado e instalado em um território de baixa ocupação humana e ambiente primitivo e atualmente apresenta aspectos urbanos e periurbanos marcantes que são os maiores responsáveis pela deterioração da sua vegetação nativa, embora ainda possua algumas áreas protegidas que podem colaborar na restituição dos corredores biológicos fundamentais na conservação da biodiversidade.

A seguir apresenta-se um levantamento realizado sobre a ocupação das margens do Lago Paranoá sendo avaliados sete momentos distintos: 1954, 1964, 1973, 1984, 1994, 1998 e 2001.

Os resultados alcançados apontam que a constituição da paisagem no Lago Paranoá, que estabelece um corredor aquático entre as áreas nucleares, está estreitamente relacionado aos intensivos processos de adensamento da malha urbana, principal responsável pela redução dos espaços naturais do cerrado circundante ao lago. 


\section{1. $1^{\circ}$ TEMPO - MAPA DE USO DO SOLO EM 1954:}

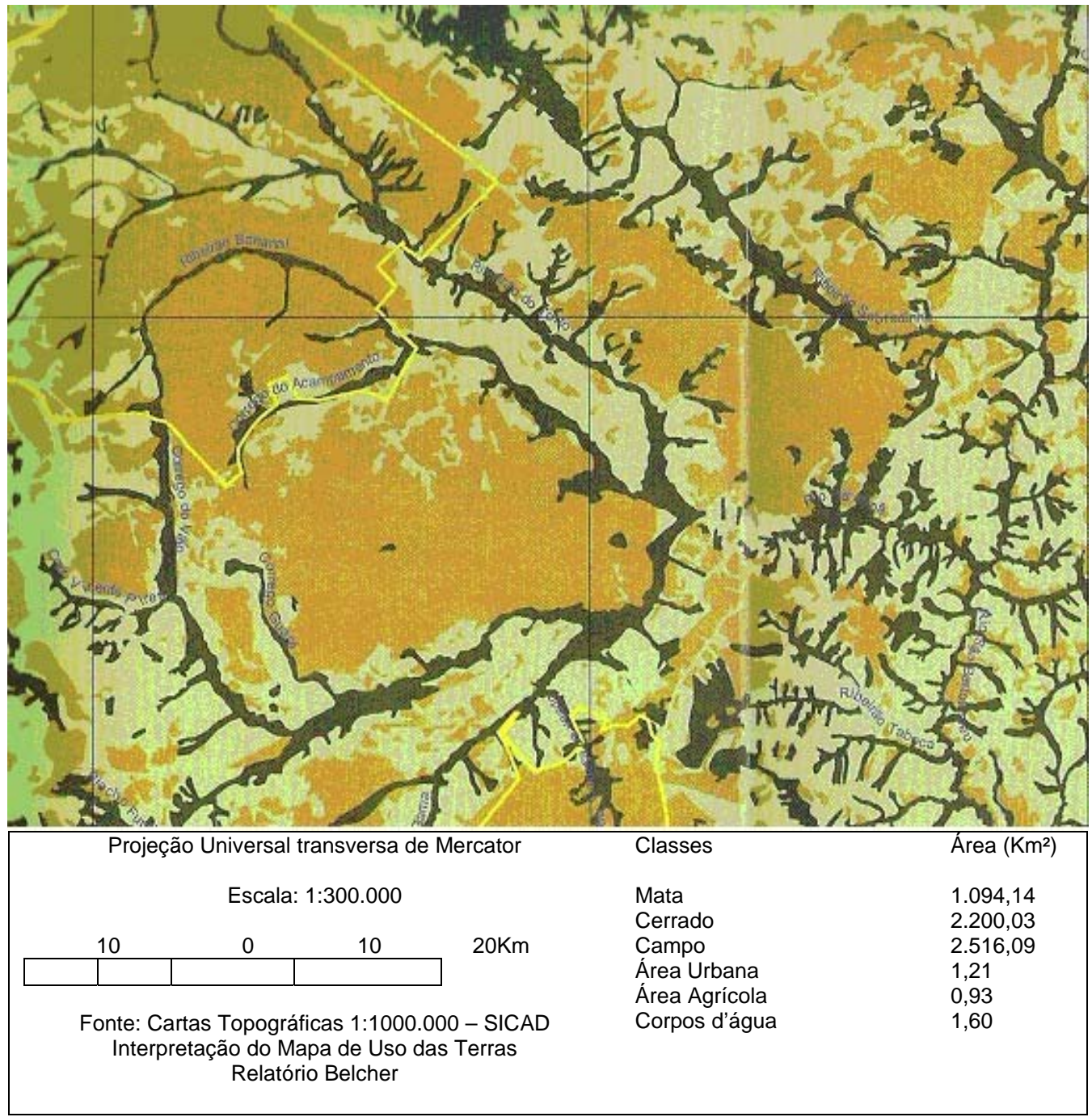

Fonte: Vegetação do Distrito Federal: Tempo e Espaço. 2.ed. Brasília, UNESCO, 2002. Obs.: Área referente ao Distrito Federal.

$\mathrm{Na}$ área de $37,50 \mathrm{~km}^{2}$ onde se localiza atualmente o espelho d'água do Lago Paranoá constata-se através do mapa acima a situação original de cobertura vegetal do ano de 1954 apresentando principalmente mata. As análises preliminares e o projeto para a construção da barragem foram realizados em 1955, item já incluído no edital do concurso para o Plano Piloto. Neste momento a orla do futuro lago é constituída por campos, cerrados e corpos d'água - Ribeirão do Torto, Ribeirão do Gama, Rio Cabeça de Veado e Rio Paranoá. Verifica-se também que não há oficialmente a presença de núcleos urbanos no espaço analisado. 


\section{2. $2^{\circ}$ TEMPO - MAPA DE USO DO SOLO EM 1964:}

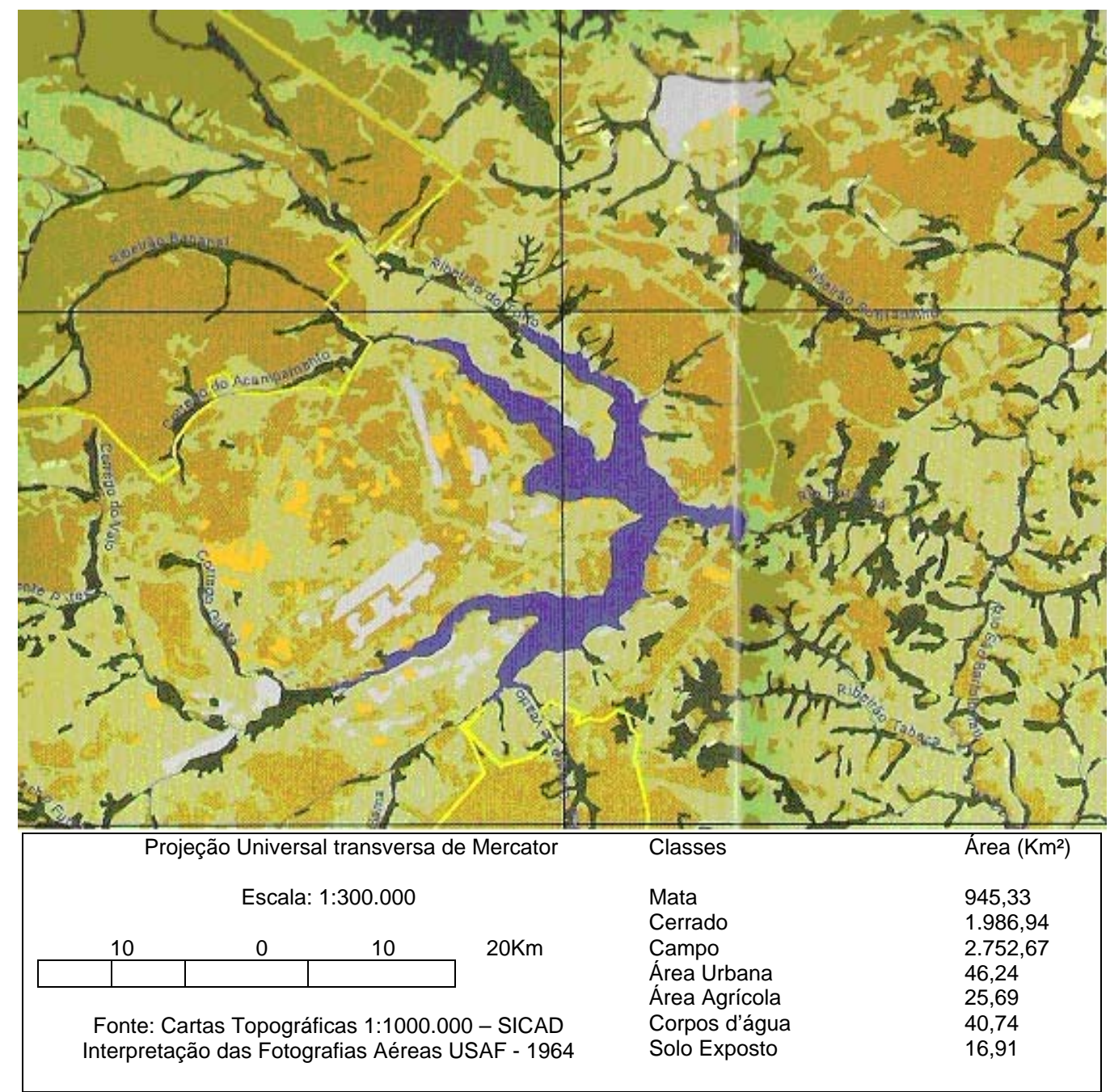

Fonte: Vegetação do Distrito Federal: Tempo e Espaço. 2.ed. Brasília, UNESCO, 2002. Obs.: Área referente ao Distrito Federal.

Neste período a barragem do rio Paranoá já se encontra construída, em 1957 iniciou-se as obras e o represamento do Rio Paranoá e riachos do Gama, Bananal, Ribeirão do Torto e Vicente Pires, inundando-se uma grande área de mata localizada ao longo destes cursos d'água. Nesta ocasião os moradores da Sacolândia e de acampamentos pioneiros, que ocupavam a área do lago foram expulsos devido á elevação do nível d'água deste. Nota-se no mapa acima que a orla da barragem apresenta várias manchas de solo exposto (cor laranjada), que foram utilizadas como áreas de empréstimos para a construção da Nova Capital. Observa-se também o início do processo de surgimento de novas áreas urbanas (cor branca). 


\section{3. $3^{\circ}$ TEMPO - MAPA DE USO DO SOLO EM 1973:}

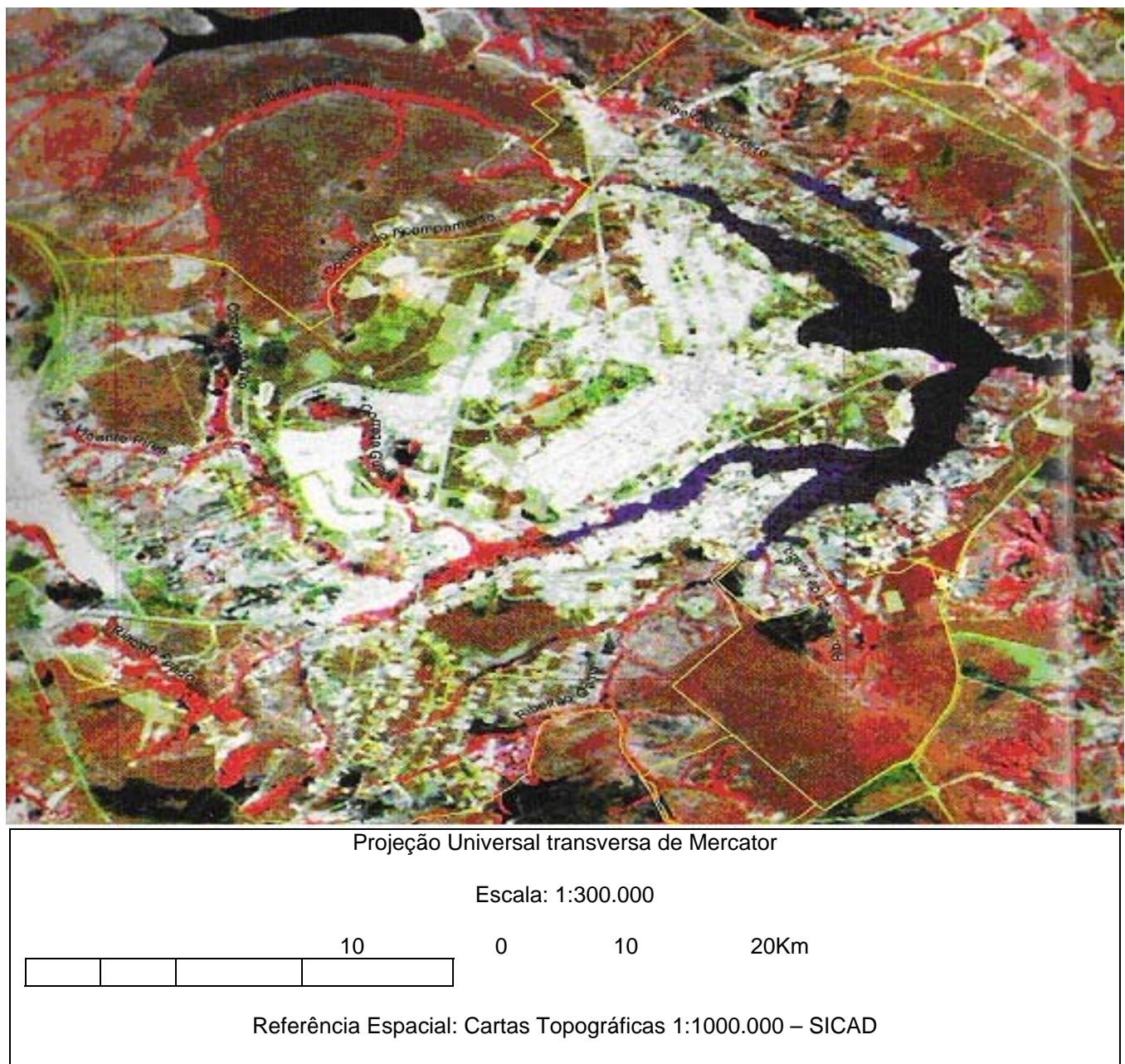

Fonte: Vegetação do Distrito Federal: Tempo e Espaço. 2.ed. Brasília, UNESCO, 2002.

O ano de 1973 é caracterizado pelo adensamento da malha urbana. Um dos pontos mais densos neste ano no Distrito Federal é o Plano Piloto, porém, constatase na carta imagem apresentada acima que a orla do Lago Paranoá já se encontra com uma ocupação urbana significativa, principalmente na sua porção Sul. 


\section{4. $4^{\circ}$ TEMPO - MAPA DE USO DO SOLO EM 1984:}
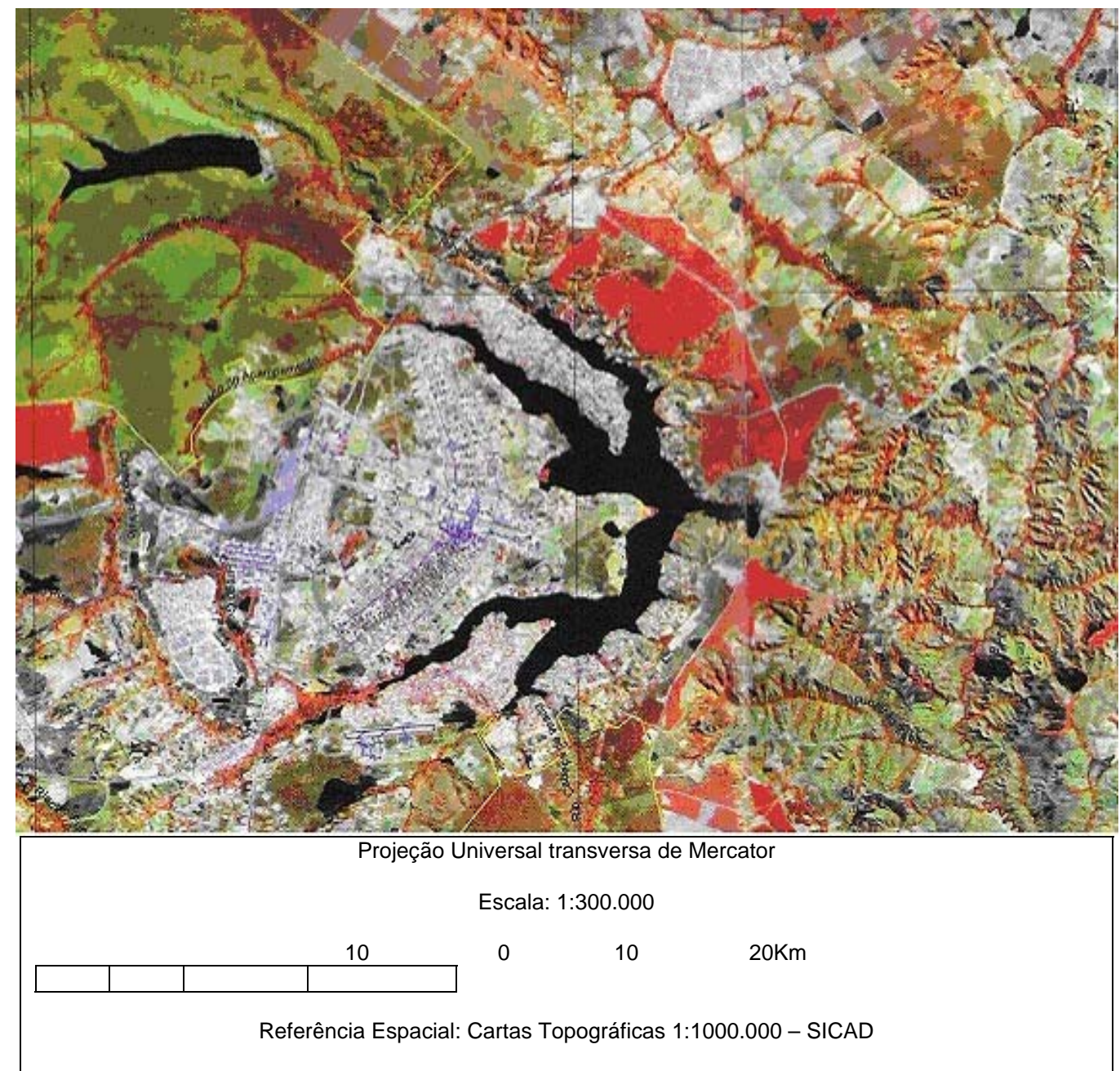

Fonte: Vegetação do Distrito Federal: Tempo e Espaço. 2.ed. Brasília, UNESCO, 2002.

Comparando-se a carta imagem de 1973 à de 1984 fica evidente o aumento populacional na orla do Lago Paranoá, que dessa vez ocorre com maior ênfase na sua porção Norte. 


\section{5. $5^{\circ}$ TEMPO - MAPA DE USO DO SOLO EM 1994:}

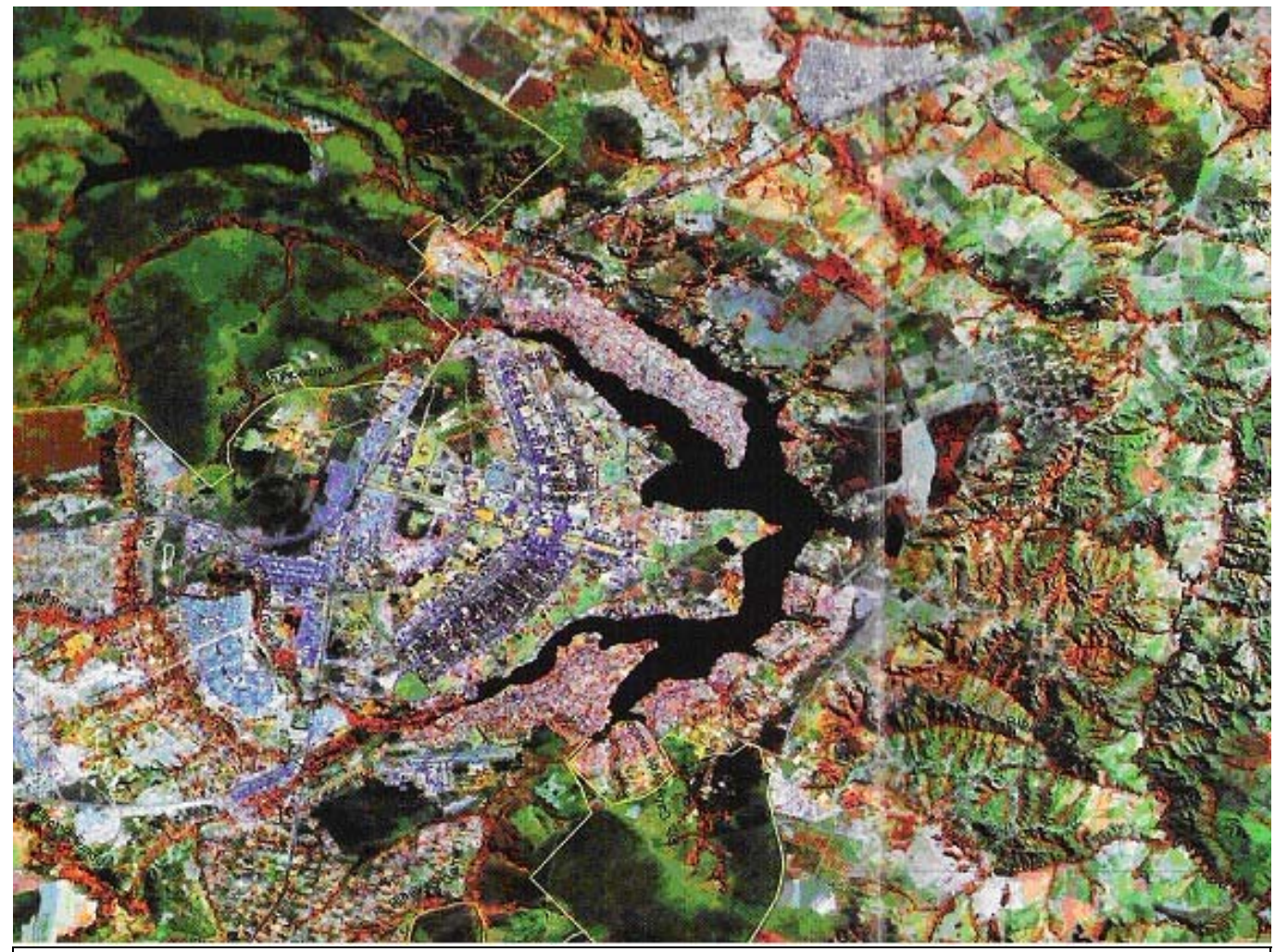

Projeção Universal transversa de Mercator

Escala: 1:300.000

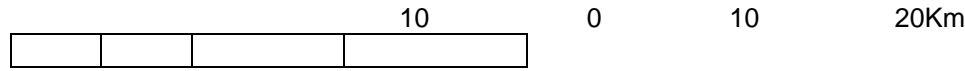

Referência Espacial: Cartas Topográficas 1:1000.000 - SICAD

Fonte: Vegetação do Distrito Federal: Tempo e Espaço. 2.ed. Brasília, UNESCO, 2002.

Esta ocasião é caracterizada pelo surgimento de novas áreas urbanas de caráter popular no Distrito Federal como, por exemplo, a Região Administrativa do Paranoá próxima à barragem do Lago Paranoá. 


\section{6. $6^{\circ}$ TEMPO - MAPA DE USO DO SOLO EM 1998:}

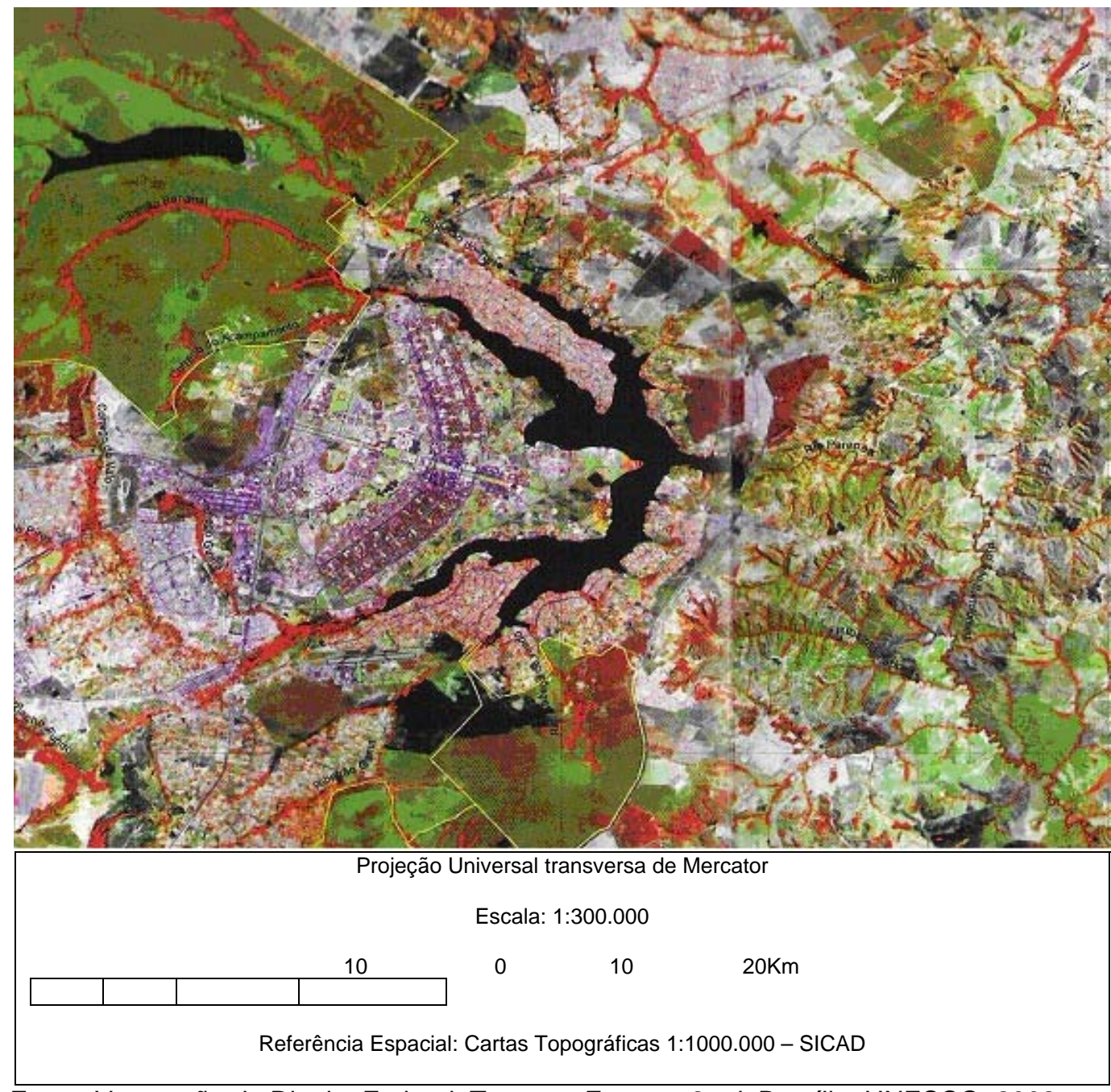

Fonte: Vegetação do Distrito Federal: Tempo e Espaço. 2.ed. Brasília, UNESCO, 2002.

Nesta ocasião a ocupação do solo na orla do Lago Paranoá apresenta-se num ritmo crescente e contínuo, as suas margens estão tomadas em grande parte por restaurantes, clubes e áreas que poderiam ser destinadas ao lazer, como as do Projeto Orla. Neste período as invasões de áreas públicas realizadas por especuladores imobiliários e proprietários de terrenos particulares agravam os problemas ambientais existentes no lago tais como o assoreamento e poluição de suas águas. 


\section{7. $7^{\circ}$ TEMPO - MAPA DE USO DO SOLO EM 2001:}

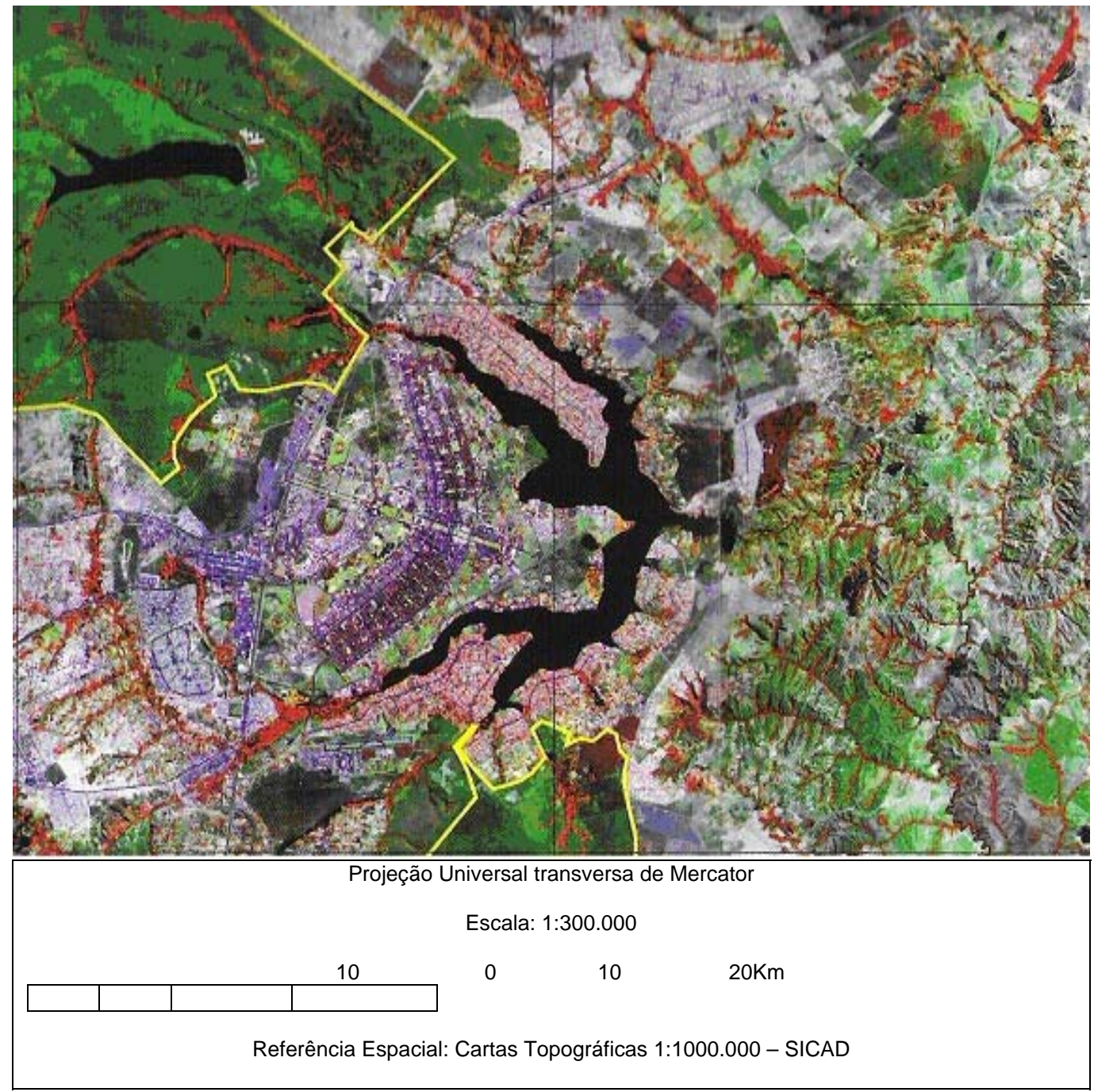

Fonte: Vegetação do Distrito Federal: Tempo e Espaço. 2.ed. Brasília, UNESCO, 2002.

Neste período algumas áreas anteriormente desocupadas e/ou abandonadas começam a ser destinadas ao Projeto Orla. Assim, já se encontravam fixadas as imagens de Orixás na "Prainha". Alguns restaurantes do Píer 21 ainda estavam sendo construídos e os hotéis próximos ao Palácio da Alvorada (Tree Towers Alvorada e Lake Side) também se encontravam em processo de construção. No Pontão Sul o "Portão Romano" e as cercas do mesmo estilo já estavam construídas, porém internamente apresentava somente a infra-estrutura necessária, plantio de árvores e iluminação especial. 


\section{5. "ORLA": O PROJETO OFICIAL}

O Projeto Orla cujo nome oficial é Plano de Ordenamento e Estruturação Turística de Brasília, no qual conceitualmente foi denominado de "Projeto Orla Revitalização do Lago Paranoá" visa o desenvolvimento urbano da orla do lago com aproveitamento turístico, econômico e social em áreas pertencentes ao Governo do Distrito Federal que o circundam.

O projeto segue a orientação do arquiteto e urbanista Lúcio Costa no que tange à utilização do lago e sua ligação com a cidade, transformando-o intensamente através da qualificação dos seus espaços, tornando possível o ingresso das pessoas e democratizando, dessa forma, a sua utilização. O Projeto Orla vem reforçar a característica bucólica do lago, ampliando a qualidade da cidade em acolhedora, turística e cultural, capaz de suavizar o Planalto Central - centro das decisões políticas do país.

O desenvolvimento do projeto se apóia em dois critérios básicos: a ampliação das alternativas de lazer à população residente no Distrito Federal e a criação de alternativas para aumentar o tempo de permanência dos milhares de passageiros que chegam à cidade. Assim, o lago estará acessível a todos e proporcionará um espaço atrativo para o turista com maiores opções de lazer, esporte, cultura e ambientes agradáveis de estadia, acentuando o interesse destes pela Capital, consolidando Brasília como pólo turístico nacional e internacional.

As normas gerais adotadas no projeto têm o propósito de não descaracterizar a concepção de Brasília. Portanto deve-se manter a orla livre para acesso e uso públicos, preservar a horizontalidade da paisagem, valorizar o patrimônio cultural da humanidade, recuperar os princípios os quais nortearam a criação da cidade e manter a predominância de espaços livres e arborizados sobre os espaços construídos, característicos da escala bucólica de Brasília. Assim, a ocupação das margens do lago com qualidade, oferecerá espaço e uma paisagem onde as pessoas sintam prazer de se encontrar e se divertir.

Um projeto de tamanha importância é impossível ser efetuado somente pelo setor público devido à falta de recursos. Foi por esse motivo que o GDF estabeleceu parcerias com empresários da iniciativa privada no sentido de executá-lo, pelo menos teoricamente, de forma mais breve e sem ter que impor certos custos sociais nessa obra, como a suspensão de recursos na saúde, educação e transportes, itens primordiais para a população. 
De acordo com o Projeto Orla, os terrenos pertencentes ao mesmo serão licitados $^{1}$ pela Companhia Imobiliária de Brasília - TERRACAP, pois a maioria pertence a ela, com exceção de algumas áreas dos calçadões que são públicas, mesmo assim o Governo do Distrito Federal delegou-Ihe a competência para efetuar também as licitações dessas áreas.

De acordo com a revista Projeto Orla, Brasília XXI "o Projeto Orla é composto por 11 pólos, planejados para funcionarem tanto no período diurno como noturno e um Calçadão, designado de Alameda que os interligam. Estão previstas várias utilizações para estes pólos, que vão desde a hospedagem às culturais, passando pelo comércio e lazer, com oferta de ambientes atrativos e de meios agradáveis de estada, tudo para aumentar o tempo de permanência do turista na cidade." 2

Conforme o projeto todos os pólos se concentrarão no Plano Piloto, com exceção do Pólo 1 - Pontão do Lago Norte, concebido para ser o principal meio de lazer da comunidade do Lago Norte e também por possuir uma relação náutica evidente.

"Em cada pólo serão permitidas diversas atividades complementares, possibilitando maior variedade e dinamismo na sua utilização. Quatro sistemas de circulação ligarão os pólos. A própria Alameda para os pedestres, uma Ciclovia, um veículo de baixa velocidade circulando paralelamente ao Calçadão e para os pólos na beira do lago, marinas públicas e pequenos atracadouros para os barcos." 3

Serão: Pólo 1 - Pontão Lago Norte; Pólo 2 - Complexo da Enseada; Pólo 3 Complexo do Brasília Palace; Pólo 4 - Parque do Cerrado; Pólo 5 - Marina do Paranoá; Pólo 6 - Centro de Lazer Beira Lago; Pólo 7 - Parque Tecnológico; Pólo 8 Centro Internacional; Pólo 9 - Parque Aquático; Pólo 10 - Parque das Nações; Pólo 11 - Pontão Lago Sul.

\footnotetext{
${ }^{1}$ A licitação é apenas para concessão de uso, por período estabelecido no contrato. Somente após o vencimento, se houver interesse das partes, poderá ser vendido.

2 in Brasília. GDF. Revista Projeto Orla, Brasília XXI. Brasília, 1995, p. 11.

3 idem $n^{\circ} 2$
} 


\subsection{REATIVAÇÃO DO PROJETO ORLA:}

Atualmente o Projeto Orla encontra-se quase que paralisado. Apesar da reforma da Concha Acústica e dos quiosques do Pólo 3 conforme o projeto inicial que tinha sido abandonado, o Governo do Distrito Federal não prioriza a revitalização do Projeto Orla. O que se nota é uma série de entrevistas e anúncios de líderes governistas elogiando o projeto, ressaltando a sua importância na geração de emprego e renda para o Distrito Federal, entretanto a prática é completamente diferente.

A Concha Acústica é um teatro ao ar livre e que já foi aproveitado para diversos acontecimentos como exposições, festas, espetáculos e vários eventos culturais. Era considerada a melhor alternativa de entretenimento popular de Brasília e um local adequado para o surgimento de novos artistas. O espaço já foi palco de inúmeros shows, acolhendo diversos artistas como Roberto Carlos, Djavan, Caetano Veloso, a banda brasiliense Nativus, sem esquecer do festival do Porão do Rock que foi realizado em 1999. Contudo o espaço encontrava-se totalmente depredado e sem condições de sediar qualquer tipo de evento. Por isso o mesmo estava fechado desde 2002.

No entanto, neste ano (setembro) a revitalização do Projeto Orla recebeu mais duas obras de lazer, cultura e turismo. A Concha Acústica e os quiosques do Pólo 3 foram totalmente reformados, vários serviços foram executados, como a recuperação das redes hidráulica e elétrica, cabine de som, bilheteria, sanitários e camarins, além das pinturas dos bancos e limpeza. Ficando o custo da obra em torno de $\mathrm{R} \$ 230$ mil. Contudo aguarda-se a abertura de licitação para a exploração dos dois espaços. ${ }^{4}$

A Concha Acústica de Brasília é um anfiteatro destinado a realizações e apresentações teatrais, shows e espetáculos ao ar livre, de viva voz, sem necessidade de ampliação eletrônica de som. Com capacidade para abrigar seis mil pessoas sentadas, numa área construída de $8.435 \mathrm{~m}^{2}$. O palco em nível inferior é dotado de concha acústica com 42 metros de comprimento e 5 metros de altura. ${ }^{5}$

\footnotetext{
${ }^{4}$ apud Jornal de Brasília, Caderno Cidades, p. 04, 27/09/2003. Vide anexo nº 10.

${ }^{5}$ Idem $n^{\circ} 4$.
} 
Recentemente tanto a população de Brasília como os turistas necessitam de espaços como esse, pois são poucos os eventos populares na cidade. De acordo com o presidente do Sindicato de Hotéis, Bares e Restaurantes - Sindobar "as pessoas não saem mais de casa. Além de serem poucas as atividades culturais na cidade, as opções que existem atualmente são muito caras. (...) Tanto os visitantes quanto os residentes querem ter o que fazer. Uma cidade que se desenvolve em torno de uma boa agenda cultural atrai as pessoas para a rua, favorecendo a utilização dos serviços de hotéis, bares e restaurantes, cinemas e teatros". ${ }^{6}$

O desenvolvimento dos setores relacionados ao turismo está intimamente ligado às atividades culturais. Conseqüentemente, com a reforma da Concha Acústica as bandas musicais ou companhias não pagarão os altos preços dos teatros e casas de espetáculos, o que encaresse o preço dos ingressos e diminui o tempo de permanência dos mesmos na cidade, prejudicando vários equipamentos relacionados ao lazer local.

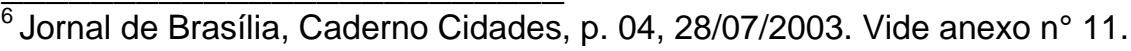




\subsection{A PRÓXIMA ETAPA:}

Segundo reportagem do Jornal de Brasília do dia 27/05/2003 "está previsto para até o final de 2004 a construção e o funcionamento do Pólo Gastronômico do Projeto Orla, que conterá restaurantes e vários empreendimentos destinados ao lazer e receberá o nome de Farol do Lago. A localização do pólo será entre a Concha Acústica e o Quality Lake Side Hotel, em uma área de 14 mil metros." 7

O investimento de $\mathrm{R} \$ 5$ milhões está sendo feito pela iniciativa privada de Brasília e possivelmente empresários do Rio de Janeiro e de São Paulo serão convidados a participar do projeto, porém, somente quando o mesmo estiver mais adiantado. A previsão é de que o projeto gere três mil empregos diretos e aproximadamente três mil indiretos. ${ }^{8}$

Além dos restaurantes, o empreendimento possuirá livrarias, tabacaria, microcervejaria que fabricará e venderá o produto, boates com apresentação de orquestras durante a semana e de DJs aos fins de semana, bar flutuante que fornecerá comida e bebida ás embarcações, capela flutuante destinada á realização de casamentos e uma escola de gastronomia e de formação de sommeliers.

De acordo com Marco Aurélio da Costa, um dos empresários que participa do grupo de responsáveis pelo projeto, sócio do restaurante Piantella, o pólo terá entre quinze e vinte restaurantes, mercado de flores e de peixes, boate, píer e capela flutuante, entre outros atrativos. (...) "Vamos trazer chefs e sommeliers de todo o país para dar aulas". Além disso, a casa funcionará como uma rotisseria (casa de venda de carnes) e pâtisserie (confeitarias francesas, onde também são vendidos produtos salgados). "E venderemos vinhos de nossa adega também", acrescenta. ${ }^{9}$

Assim, se forem seguidos todos os "passos" do projeto e se futuramente bem administrado a previsão é de que o Pólo Gastronômico seja mais um impulso para o turismo de lazer na Capital Federal, conforme a revitalização do Projeto Orla.

\footnotetext{
$\overline{7}$ Jornal de Brasília, Caderno Cidades, p. 06, 27/05/2003. Vide anexo nº 13.

${ }^{8}$ Idem $\mathrm{n}^{\circ} 7$.

${ }^{9}$ Ibdem n ${ }^{\circ} 8$.
} 


\section{OCUPAÇÃO TERRITORIAL DA ORLA DO LAGO PARANOÁ:}

As ocupações ilegais de terras e espaços públicos são questões em que poder público do Distrito Federal perdeu o controle, talvez por omissão, o que resultou na ousadia dos invasores. Pode-se afirmar que as invasões de terras já fazem parte da cultura do Distrito Federal caso fossemos analisá-las historicamente. Contudo, tal prática não distingue classe social, pois do nobre ao mais humilde morador de Brasília já aderiu de tal meio objetivando a posse de terras, sem que o poder público atue de forma eficaz para conter tais excessos.

No caso específico da orla do Lago Paranoá são inúmeros os fundamentos utilizados pelos moradores para tal prática. As justificativas vão desde o abandono das áreas verdes por parte dos órgãos do governo, com o conseqüente crescimento de mata e o acúmulo de lixo e entulho, à segurança, ameaça dos delinqüentes que se utilizam dessas áreas para invadirem as propriedades particulares.

Nos Setores de Mansões do Lago Norte e de Clubes e Hotéis Sul e Norte, em que os terrenos fazem limite com o lago, as Normas de Gabarito (NGBs) relacionadas à construção de equipamentos voltados para a atividade náutica como marinas, píeres, muros de arrimos e aterramentos não atuam de forma efetiva prevenindo ou coibindo práticas irregulares, o que implica em sérios agravos ao meio ambiente.

A legislação existente sobre ocupação e construção na orla é dispersa e de responsabilidade de diferentes atores. A legislação da Marinha é voltada, fundamentalmente, para as questões da segurança da navegação, deixando sob a responsabilidade do governo local (SEDUH e Administrações Regionais) os aspectos urbanísticos e edilícios das construções. As questões ambientais, abordadas no Código Florestal, nas Resoluções CONAMA e na legislação local, são da alçada da SEMARH, da Delegacia do Meio Ambiente - DEMA, e do Ministério Público do Distrito Federal e Territórios - MPDFT, por intermédio da Prodema. Os aspectos relativos ao tombamento de Brasília, como Patrimônio Cultural da Humanidade são de responsabilidade da Prourb e do Instituto do Patrimônio Histórico e Artístico Nacional - IPHAN. ${ }^{10}$

No que se refere às ocupações na orla do lago, existe um agravante por se tratar de área de preservação permanente, conforme o Código Florestal (Lei $n^{\circ}$ 4.771, de 15 de setembro de 1965) e a Resolução CONAMA $n^{\circ}$ 004, de 18 de dezembro de 1985, que exigem 30 metros de área de preservação permanente (APP) em volta das lagoas, lagos ou reservatórios, e 100 metros de APP em torno de represas hidrelétricas, como é o caso do Lago Paranoá. ${ }^{11}$

\footnotetext{
${ }^{10}$ apud Fernando Oliveira Fonseca, Olhares sobre o Lago Paranoá, pág. 74.

${ }^{11}$ Idem $\mathrm{n}^{\circ} 10$.
} 
O código só permite a supressão total ou parcial de florestas ou outros tipos de vegetação de preservação permanente com prévia autorização do Poder Executivo Federal, e somente quando é necessária à execução de obras, planos, atividades ou projetos de utilidade pública ou interesse social. ${ }^{12}$

Em novembro de 2000 foi realizado um amplo debate na Câmara Legislativa do Distrito Federal, cujo tema foi à cobrança de taxas para a utilização dos espaços públicos. A respectiva medida foi aprovada e assim o poder público assumiu a fiscalização dos mesmos. Foram estabelecidos regras e parâmetros sobre a ocupação de áreas públicas e certas irregularidades receberam o aval do poder público local, pois só bastaria pagar uma simples taxa de ocupação do espaço público; assim a ilegalidade virou legalidade. No mesmo debate os espaços verdes residenciais foram isentos de taxas. Portanto, o assunto foi abreviado a uma simples cobrança de taxas não se valorizando de nenhuma forma a questão ambiental.

Em 2003 foi realizado o seminário "Gestão Participativa e Integrada do Lago Paranoá", na Universidade Católica de Brasília (UCB). Os debates asseguraram o valor da Bacia do Paranoá e dos seus recursos hídricos para a cidade. No que tange a defesa e preservação do lago, conclui-se que é extremamente importante concretizar a criação do Comitê de Gestão da Bacia do Paranoá e sensibilizar o governo local da sua importância.

O Comitê Gestor da Bacia do Paranoá é o responsável pelo planejamento, distribuição e utilização de forma integrada e sustentável dos recursos hídricos. O uso e ocupação do solo que atualmente está diretamente interligado à água no Distrito Federal deverão ser aprovados pelo comitê, que não tem o poder de fiscalização do Estado, mas pode pressioná-lo para que a preservação aconteça de forma concreta.

O comitê ainda não existe por falta de vontade política e estrutura organizacional do governo. Por lei, ele já deveria ter sido criado em 2001, quando foi aprovada a Lei das Águas do DF (Lei 2725/2001), mas até agora não saiu do papel. No DF, o poder público tem sido o grande dificultador da formação de comitês, quando nos outros estados é o contrário. (...) Ainda não há vontade política de se valorizar medidas de gestão de recursos hídricos. ${ }^{13}$

O que se observa de forma concreta atualmente são os discursos de aversão do poder público e da sociedade à questão, porém, os mesmos não agem efetivamente e as ocupações progridem diariamente. Observa-se uma enorme quantidade de pedidos para o licenciamento ambiental de píeres e marinas, contudo não existe uma regra específica que regulamente os pedidos.

\footnotetext{
${ }^{12}$ apud Jornal de Brasília, Caderno Cidades, p. 06, 27/05/2003. Vide anexo nº 20.

${ }^{13}$ Jornal de Brasília, Caderno Cidades, p. 12, 14/05/2003. Vide anexo nº 27.
} 
Executar a legislação é o mínimo esperado, uma vez que é somente através dessas medidas que se poderá frear essa grave ocupação desordenada na margem do lago e disciplinar as ocupações atuais, ordenando a ocupação da orla do Lago Paranoá através de regras para as diversas construções de píeres, rampas para embarcações, cais e similares.

Entretanto, de nada adianta preceitos eficientes sem que o poder público adote ações concretas que coíba tais ilegalidades e por fim discipline e organize a orla do Lago Paranoá. 


\subsection{AS PROPRIEDADES QUE FAZEM DIVISA COM O LAGO:}

A ocupação antrópica na margem do lago acelerou-se nos últimos anos e conseqüentemente forçou a elaboração de uma legislação que a regulamentasse. Assim sendo, atualmente os proprietários de terrenos que fazem limite com o Lago Paranoá que pretendem efetuar qualquer tipo de construção sob, sobre ou às margens do lago devem ter a autorização da Administração Regional da respectiva região, que divulgará o resultado do pedido após divulgação do parecer da Capitania dos Portos e da SEMARH.

As construções quando situadas em área tombada, deverá ser consultado além dos respectivos órgãos citados anteriormente também o Patrimônio Histórico e Artístico Nacional - IPHAN.

O Código das Águas na Lei Federal e Distrital e o Código Florestal definem a correta forma de ocupação das margens do lago e estabelecem que a sua vegetação natural está localizada em área de preservação permanente.

A área de preservação permanente em volta do Lago Paranoá tem no mínimo 30 metros de largura, que são medidos horizontalmente, a partir do nível mais elevado das águas, conforme Resolução CONAMA nº 04/85.

A faixa marginal de $30 \mathrm{~m}$ (trinta metros) de preservação permanente em torno do Lago Paranoá, por estar inserida em área urbana, poderá ter sua ocupação disciplinada pelos Planos Diretores Locais de Brasília, Lago Sul e Lago Norte, conforme assegurado no Código Florestal, Lei 4.771/65, sem prejuízo de dispositivos da legislação em vigor, afetos à questão, a seguir discriminados:

I - As áreas que integram a Zona de Vida Silvestre da APA do Paranoá, definida no Decreto $12.055 / 89$, são destinadas exclusivamente à preservação dos ecossistemas e biota, não sendo passível de qualquer ocupação ou alteração.

II - As edificações, instalações ou exercício de atividades que ofereçam risco de poluição das águas, assoreamento ou qualquer outro dano ambiental ao Lago Paranoá, não poderão ser permitidos, conforme restrições estabelecidas no Decreto $\mathrm{n}^{\mathrm{0}}$ 12.055, de 14 de dezembro de 1989.

III - A preservação da escala bucólica - elemento da concepção urbanística da cidade, que lhe confere o caráter de cidade-parque - da qual o lago é o maior monumento, prevista no Decreto $n^{\circ} 10.829$, de 14 de outubro de 1987, deverá dar-se de modo a prevalecer a cobertura vegetal do Cerrado nativo ou das áreas arborizadas na forma de bosque, evitando-se, ao máximo, a impermeabilização do solo. ${ }^{14}$

\footnotetext{
${ }^{14}$ Fernando Oliveira Fonseca, Olhares sobre o Lago Paranoá, pág. 77.
} 
No entanto, constata-se que na orla do Lago Paranoá quase todas as residências possuem algum tipo de construção na sua margem que fere vários regulamentos ambientais e não apresentam nenhum licenciamento. Estas construções provocam, entre outras conseqüências, a redução do espelho d'água do lago que já se encontra em situação crítica.

Não é novidade que vários proprietários desobedecem à devida legislação - a 30 metros do lago é área de permanente proteção. Para aumentar o terreno os mesmos utilizam vários artifícios como o aterro das margens para posterior construção e se fundamentam no medo da violência e na exigência de privacidade.

Os casos são muitos, mas, ainda assim, a Administração não tem controle sobre o número de áreas irregulares nem mantém uma fiscalização intensiva para impedir o avanço das construções. ${ }^{15}$

Os muros de arrimo para aterro ou para conter erosões são permitidos até o limite do espelho d'água, sendo proibido o aterramento das águas do Lago Paranoá e deverão reproduzir o desenho da orla natural do lago. Estes seguem padrões de distância e altura porém alguns proprietários dos lotes denominados pontas de picolé sem a devida licença ambiental instalam grades dentro do lago impedindo qualquer pessoa de utilizar seus píeres, que devem ser obrigatoriamente de uso público.

A conseqüência do descaso da sociedade e do poder público está no assoreamento, problema que atinge os lagos urbanos e que poderá acabar futuramente com o principal ambiente de lazer de Brasília, pois o processo é irreversível, mas ainda pode-se adotar medidas corretivas e impedir o seu avanço.

As previsões não são nada otimistas: "Daqui a 50 anos, as gerações futuras brasilienses podem não ter o Lago Paranoá como ele é hoje. Desde que foi criado, na década de 60, o lago vem sofrendo com a redução do seu espelho d'água. Segundo estudos de especialistas, desde então o Paranoá diminuiu 2,3 quilômetros quadrados, área equivalente a 213 campos de futebol." ${ }^{16}$

A exigência do lago por atitudes adequadas quanto ao aspecto ambiental é evidente, pois, além das atividades voltadas ao lazer, dos fins paisagístico e urbanístico que representam a peculiaridade bucólica do lago, o mesmo adquiriu outras finalidades essenciais como dissolver e transportar esgoto tratado, captar as águas pluviais e gerar energia, assumindo uma função de destaque na cidade.

A legislação em vigor é muito ampla necessitando padronizar e regulamentar o que é permitido ou não construir na orla e Brasília deve incluir isso no seu Plano Diretor Local - PDL.

\footnotetext{
$\overline{15}$ Jornal de Brasília, Caderno Cidades, p. 03, 09/04/2003. Vide anexo n²0.

${ }^{16}$ Jornal de Brasília, Caderno Cidades, p. 09, 11/04/2003. Vide anexo nº 24.
} 


\section{2 - AS PROPRIEDADES QUE INVADEM ÁREA PÚBLICA:}

A prática da invasão de áreas públicas em Brasília não está sendo somente uma característica das áreas de baixa renda, sendo atualmente constatada nos locais de elevada valorização imobiliária como o Lago Sul e a Península Norte.

Os terrenos desses pontos cuja área original é de $800 \mathrm{~m}^{2}$ estão situados em uma área de previsão de um espaço público na orla, contudo não foi realizada a devida infra-estrutura designando-se os acessos como vias e passeios públicos, acarretando em invasões realizadas por propriedades próximas a esses espaços, que acabaram avançando sobre a orla ocasionando séria degradação ambiental.

Atualmente é permitido aos moradores ocuparem áreas públicas, desde que obedeçam as devidas legislações no que diz respeito ao Código de Edificações e Posturas do DF, às normas de uso e ocupação do solo, normas ambientais e da Capitania dos Portos e as demais normas exclusivas a cada tipo de atividade a ser praticada. Os mesmos necessitam de uma autorização que será outorgada somente ao proprietário do imóvel ou a seu representante legal para tal pratica e compete à Administração Regional suspendê-la a qualquer momento desde que haja interesse público sem que o proprietário tenha direito a qualquer tipo de indenização.

De acordo com a legislação peculiar os proprietários são obrigados a assegurar uma área de quatro metros de largura que será destinada ao acesso público, podendo assim ser utilizada para atividades relacionadas ao lazer. Contudo, estes infringem as normas e cercam além do limite permitido atingindo a margem do Lago Paranoá degradando assim a vegetação natural e causando graves impactos sobre a flora e a fauna nativa.

Os equipamentos instalados no espaço público tais como aparelhamento relacionado à atividade náutica, guarda-sóis, quiosques, jardins e similares, adjacente à propriedade deverão ser removíveis não sendo permitido construções permanentes. Construções como píeres, rampas para embarcações, muro de arrimo e similares, deverão obedecer às normas competentes sendo consideradas permanentes e incorporadas automaticamente ao patrimônio público.

Infelizmente as irregularidades na ocupação do solo não se restringem somente ás construções irregulares e as invasões de áreas públicas, estando também envolvidos outros fatores. Há, também, captação de água com bombas destinadas à irrigação de áreas verdes, lançamento de esgotos no lago, posto de combustível sem licenciamento ambiental e aterramentos ilegais. ${ }^{17}$

\footnotetext{
${ }^{17}$ Jornal de Brasília, Caderno Cidades, p. 10, 25/07/2003. Vide anexo nº 21.
} 
Atualmente tal pratica acarreta em punições como notificação em que o proprietário fica obrigado a apresentar um posterior plano de recuperação de áreas degradadas (Prad) em no máximo 30 dias, processos na justiça por crime ambiental e até prisão no caso de flagrante, contudo a necessidade real é de uma fiscalização preventiva e eficaz e que faça cumprir a legislação existente.

Vale destacar que as áreas destinadas à utilização do público para lazer e recreação devem ser identificadas e protegidas bem como realizada também a infraestrutura adequada evitando-se a ocupação indevida. Resgatando-se assim a vocação original do Lago no que diz respeito a sua escala bucólica aprimorando os benefícios do turismo de lazer em Brasília e o Projeto Orla. 


\section{RESULTADO DAS ENTREVISTAS EXECUTADAS:}

- Na Caesb a pesquisadora entrevistou o coordenador de marketing da empresa, que relatou que o Lago Paranoá há alguns anos atrás se encontrava em uma situação lastimável, extremamente poluído e em processo de eutrofização, devido à grande quantidade de lixo que existia no seu leito, mas que hoje esta situação foi revertida, afirmando que "o lago hoje está liberado para o banho e atividades voltadas à prática de esportes náuticos". O mesmo relatou que no ano de 1998, foi realizada uma grande operação de limpeza do lago, envolvendo o governo da época, Ong's, algumas instituições públicas como a Caesb e a população local, na qual foi retirada mais de 200 toneladas de lixo e assegurou que essa operação seria repetida neste ano - 2003 e estaria sob o comando do Comitê da Bacia do Paranoá, porém a autora constatou que tal fato não aconteceu. Ao ser indagado sobre a Estação de Tratamento de Esgoto da Caesb que se encontra nas proximidades da Faculdade Euro-Americana o mesmo relatou que a Caesb adota todas as providências cabíveis procurando minimizar ao máximo os transtornos na área e que o único desconforto para quem mora e/ou transita no local é o mau cheiro e que tem a consciência de que tal fato é prejudicial ao turismo. A pesquisadora perguntou se a Caesb não poderia adotar algum tipo de providência para minimizar esta situação e o entrevistado relatou que isso não poderia ser feito não dando maiores explicações. Também foi perguntado se existe algum perigo da estação estar poluindo o solo das proximidades e a água do lago e o entrevistado negou tal fato afirmando que a Caesb adota todos os procedimentos de segurança, utilizando equipamentos de última geração e funcionários qualificados dentro da Estação.

- De acordo com entrevista também realizada no departamento de fiscalização da TERRACAP com o supervisor do SEVIC - Serviço de Vigilância e Controle, dentre todos os 11 pólos do Projeto Orla somente o Pólo 11 - Pontão do Lago Sul é que está em estágio mais avançado das obras, infra-estrutura e conseqüentemente de funcionamento. No mesmo pólo já foram implantadas algumas lojas de esportes náuticos, aluguel de lanchas, restaurantes, bares e já estão sendo realizadas algumas feiras como a Feira do Sol e da Lua por exemplo. O mesmo relatou que neste ano - 2003 o Governo do Distrito Federal priorizou a reforma da Concha Acústica e dos quiosques do Pólo 3 e que atualmente já se encontram em condições de funcionamento, porém, aguarda-se licitação que será realizada pela própria TERRACAP. A entrevistadora indagou que existem áreas públicas na orla do lago destinadas ao lazer público que estão sendo invadidas por moradores locais e se a TERRACAP estaria tomando alguma providência em relação a este acontecimento. $O$ entrevistado afirmou que a TERRACAP não tem responsabilidade alguma sobre este fato e que compete às Administrações Regionais dos Lagos Sul e Norte, à Semarh e ao Ibama fiscalizar e adotar medidas que previnam e combatam estes crimes ambientais. 


\section{CONCLUSÃO:}

Não há dúvida de que o Lago Paranoá é a melhor opção de entretenimento de Brasília. Criado por Lúcio Costa para este fim, hoje se tornou com a reformulação do Projeto Orla o maior sonho de se conseguir impulsionar o setor turístico da Capital Federal, pois através de tal projeto Brasília pode mostrar para o resto do país e para o mundo que não é somente um Centro Administrativo, uma cidade que prepondera através dos turismos de negócios, de viagens e de eventos e que não apresenta opções de lazer que atraiam estes turistas e sim estimule a permanência dos mesmos na cidade contribuindo com o aumento da demanda turística. Simultaneamente a cidade poderá atender a sua população em um quesito primordial que é a questão do emprego e da renda e assumir uma função de destaque no cenário nacional e internacional do turismo de lazer.

O Projeto Orla não visa somente o turista mas também a população local que poderá se integrar ao lago e à sua orla, porém, o seu sucesso encontra-se ameaçado. Quando formulado por Lúcio Costa, as áreas ao redor do lago tinham como objetivo a destinação ao lazer, contudo o que se vê hoje é a absoluta falta de planejamento urbano nesta região, o surgimento nos últimos anos de inúmeros condomínios e invasões de terras realizadas por proprietários de terrenos particulares que querem ver as suas mansões cada vez maiores e não medem esforços para invadirem área pública, assim a pressão no seu meio ambiente está tendo como grave conseqüência o assoreamento que é irreversível e a poluição.

A construção dos 11 pólos do Projeto Orla ainda caminha a "passos lentos" e esta é uma questão que não depende somente do GDF mais principalmente da iniciativa privada, pois é da onde sairão os recursos necessários para deslanchar o projeto, e também dos acordos que serão realizados entre as partes e das licitações.

No Pólo 3 - Complexo Brasília Palace os hotéis Blue Three Alvorada e o Lake Side já estão construídos e funcionando normalmente, o Museu de Arte Moderna está necessitando de reformas, a Concha Acústica e os quiosques próximos estão reformados, porém, a área adjacente ao seu estacionamento necessita de reparos e de infra-estrutura adequada como a limpeza do terreno por exemplo.

O Pólo 11 - Pontão do Lago Sul é o que está mais adiantado, apresentando infra-estrutura adequada, restaurantes e bares, pequeno comércio, feiras e atracadouro para barcos. A "Prainha" muito freqüentada pela população humilde também se encontra com infra-estrutura adequada e o Shopping Píer 21 está em amplo funcionamento. O Pólo 6 - Complexo Beira-Mar, que tinha a previsão de efetivar a sua construção após a edificação da Ponte Jk, ainda aguarda por ações concretas. 
Percebe-se que atualmente não existe vontade política que vise a total execução do Projeto Orla, mesmo com os excelentes benefícios que o projeto acarretará a Brasília e que infelizmente a prioridade do GDF continua sendo a construção de obras mirabolantes, deixando assim o turismo da cidade a segundo ou quem sabe a terceiro plano. 


\section{REFERÊNCIAS BIBLIOGRÁFICAS:}

Beni, M. Análise Estrutural do Turismo. 2. ed. São Paulo, Senac, 1998.

Brasília: Brasil está aqui. Brasília: Embratur, 2000. CD-ROM.

Cavalcante, C. Meio Ambiente, Desenvolvimento Sustentável e Políticas Públicas. 3. ed. Recife, Cortez, 2001.

Fonseca, Aline. Grupo quer acelerar criação do Comitê Gestor do Lago. Jornal de Brasília. Brasília,14/05/03, Cidades, Notícias, pág. 12.

Fonseca, Aline. Obra toma espaço do Paranoá. Jornal de Brasília. Brasília, 09/04/03, Cidades, Notícias, pág. 03.

Fonseca, F. Olhares sobre o Lago Paranoá. 1. ed. Brasília, Secretaria de Meio Ambiente e Recursos Hídricos, 2001.

Gestão Ambiental e Meio Ambiente no DF. Brasília: Secretaria de Meio Ambiente e Recursos Hídricos do DF, 2000. CD-ROM.

Pellegrinni, A. Dicionário Enciclopédico de Ecologia e Turismo. São Paulo, Malone, 2000.

Plano Estratégico de Turismo - Políticas, Estratégias e Programas. Brasília, SETUR - GDF,1999 - 2002.

Revista Projeto Orla, Brasília XXI. Brasília, GDF, 1995.

Rodrigues, A. Turismo e ambiente: reflexões e propostas. 3. ed. São Paulo, Hucitec, 2002.

Sites da Internet - http://www.semarh.df.gov.br/> acesso em 18 set 2003 e 08 out 2003; http://www.setur.df.gov.br/> acesso em 19 ago 2003 e http://www.so.df.gov.br />acesso em 10 set 2003 e 15 set 2003.

Swarbrooke, J. Turismo Sustentável: conceitos e impacto ambiental. 2. ed. São Paulo, Aleph, 2000.

Vegetação do Distrito Federal - Tempo e Espaço. 2. ed. Brasília, UNESCO, 2002.

Vieira, Marcio. Projeto Orla terá Pólo Gastronômico. Jornal de Brasília. Brasília, 28/05/03, Cidades, Notícias, pág. 10. 
10. ANEXOS:

- Anexo A: Fotos registradas na orla do Lago Paranoá em dezembro de $2003\left(n^{\circ} 1\right.$ ao $\left.n^{\circ} 5\right)$.

- Anexo B: Mapas relacionados ao Lago Paranoá e ao Projeto Orla ( $n^{\circ} 6$ ao $\left.n^{\circ} 8\right)$.

- Anexo C: Reportagens de jornais locais sobre o Projeto Orla ( $n^{\circ} 9$ ao $\left.n^{\circ} 13\right)$.

- Anexo D: Reportagens de jornais locais sobre o lazer aquático no Lago Paranoá (n14 ao $\left.n^{\circ} 18\right)$.

- Anexo E: Reportagens de jornais locais sobre as obras no Lago Paranoá e Meio Ambiente ( $n^{\circ} 19$ ao $\left.n^{\circ} 27\right)$. 
Lagoa do Jaburu - Proximidades

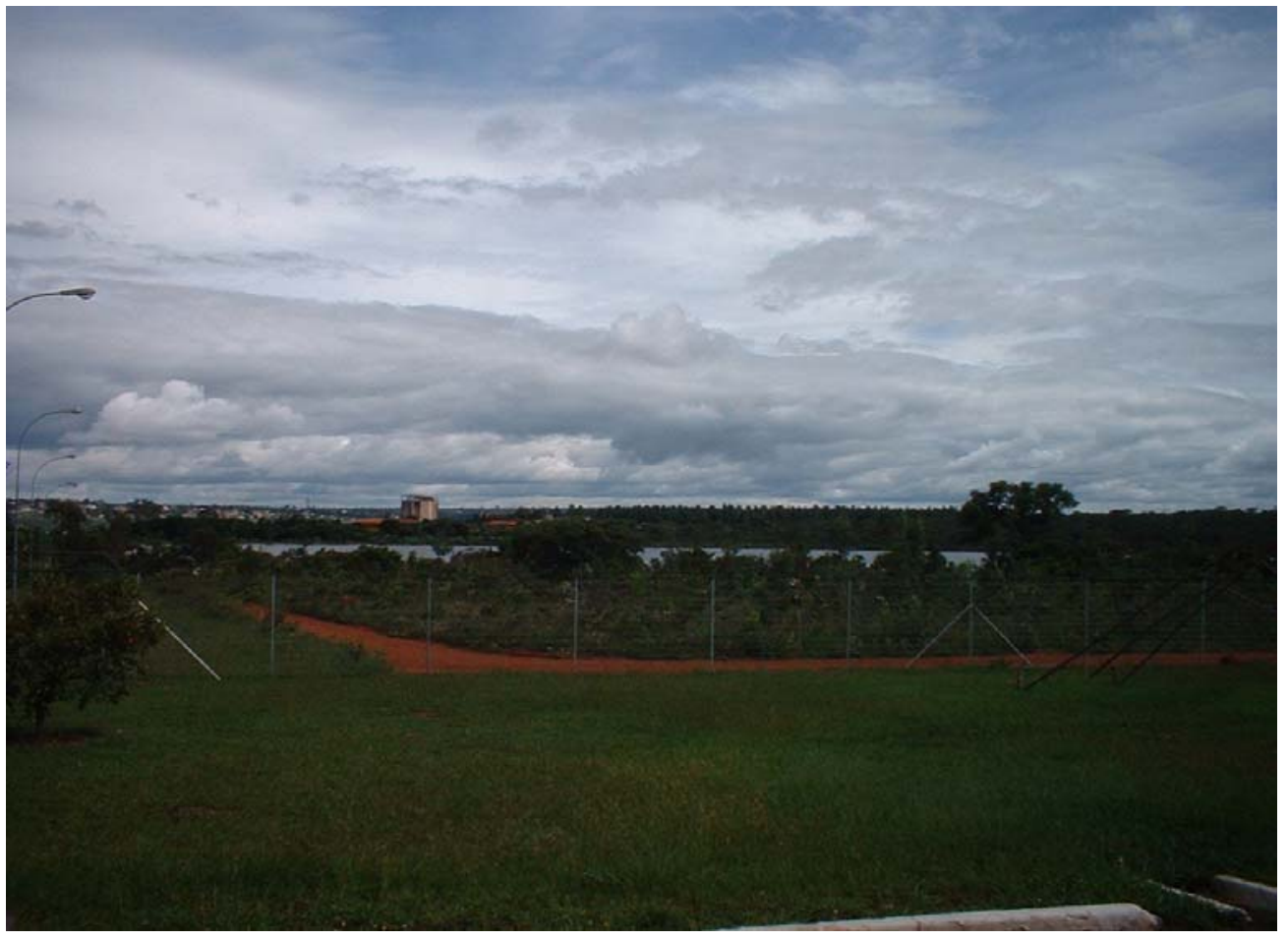

Blue Three Alvorada

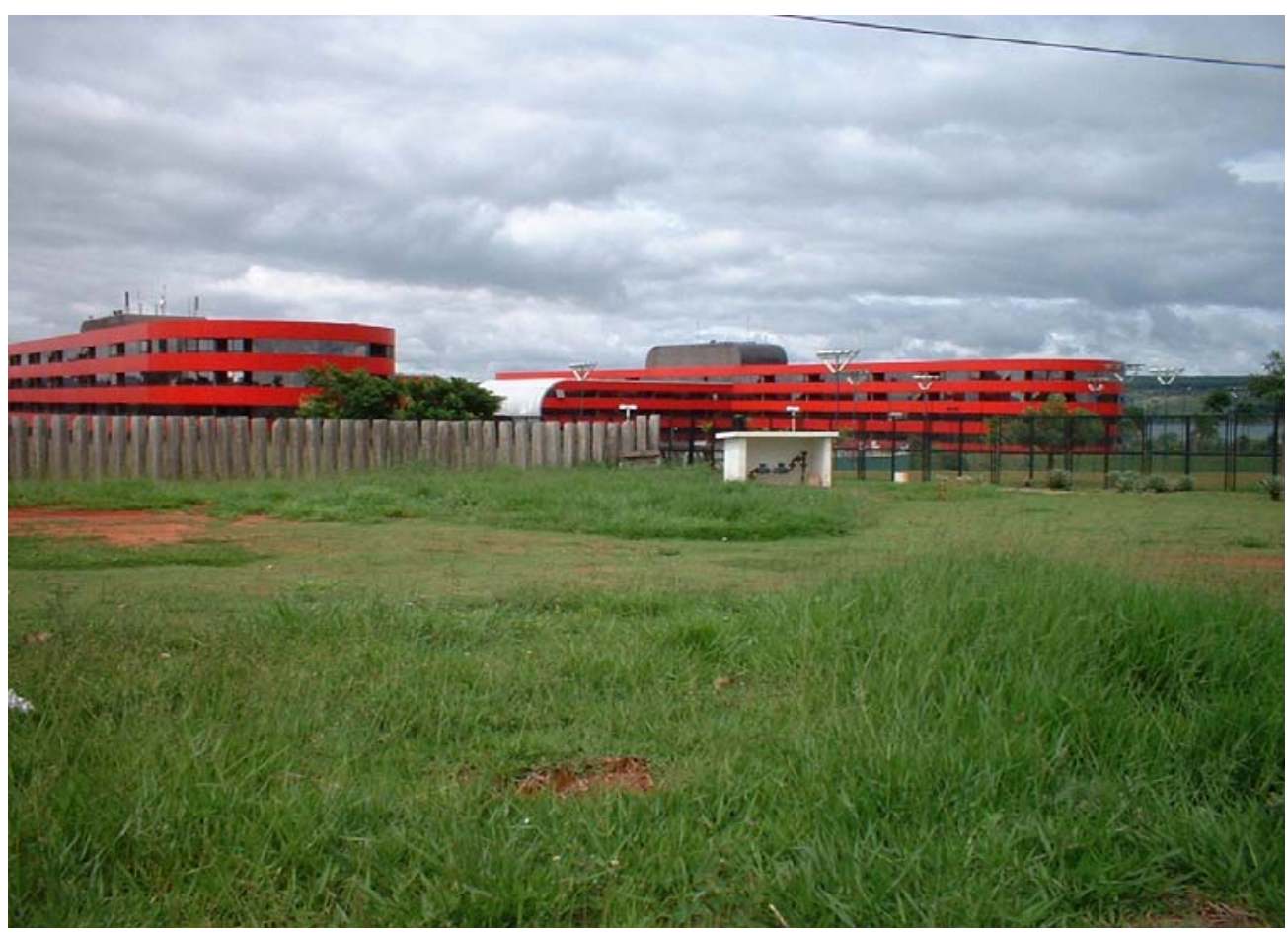


Concha Acústica

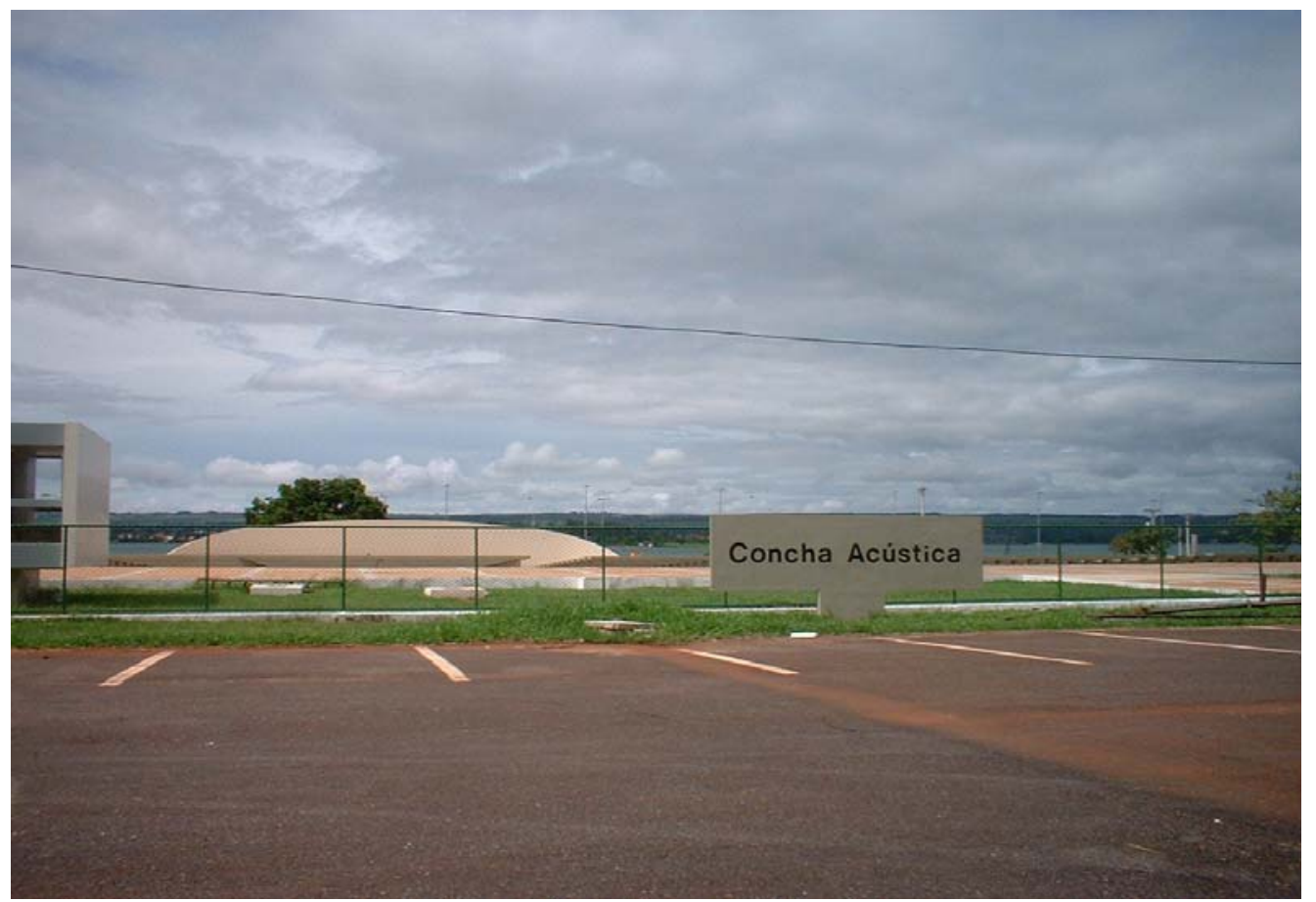

Lake Side - Vista a partir das proximidades da Concha Acústica

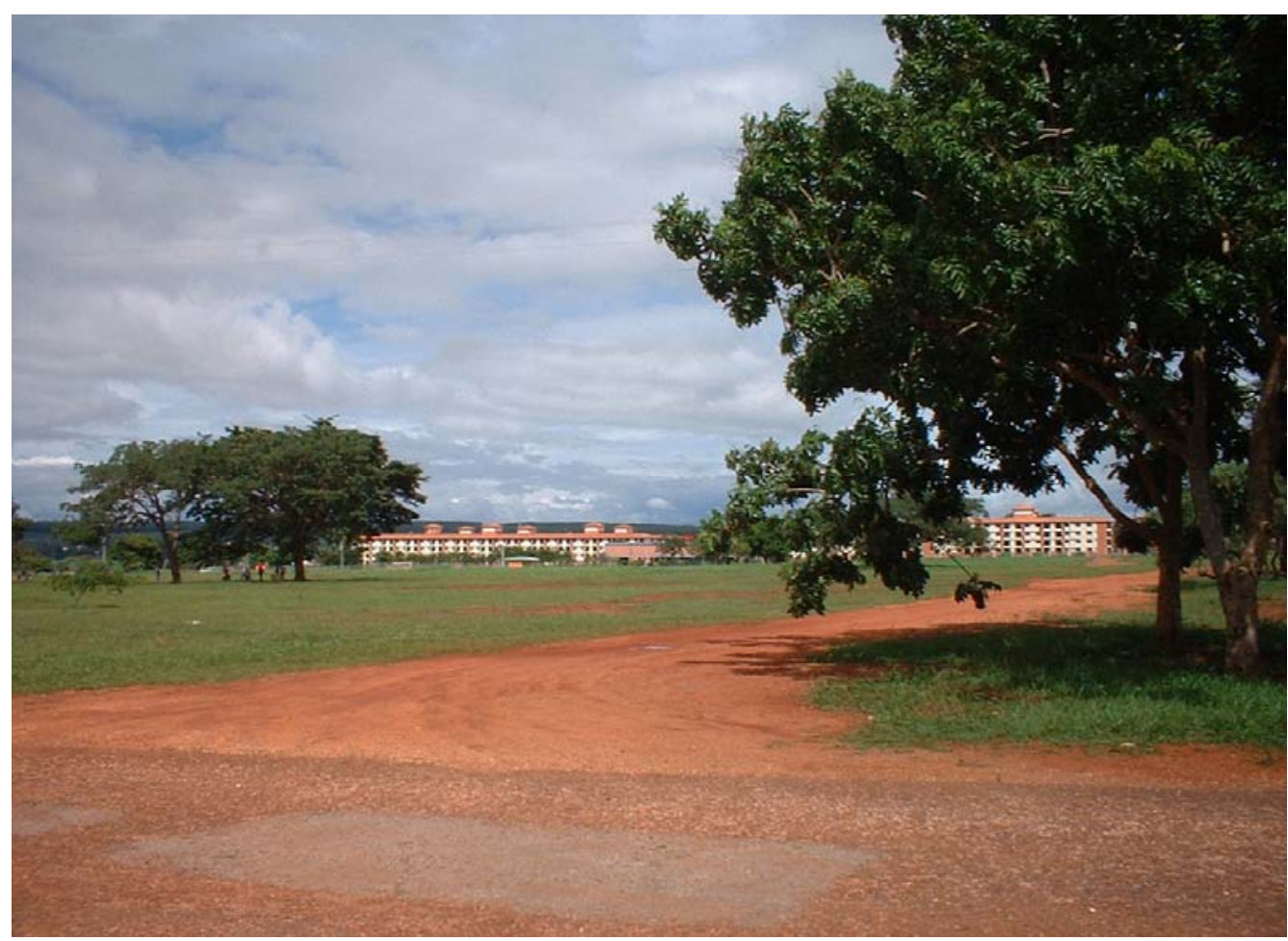


Lake Side

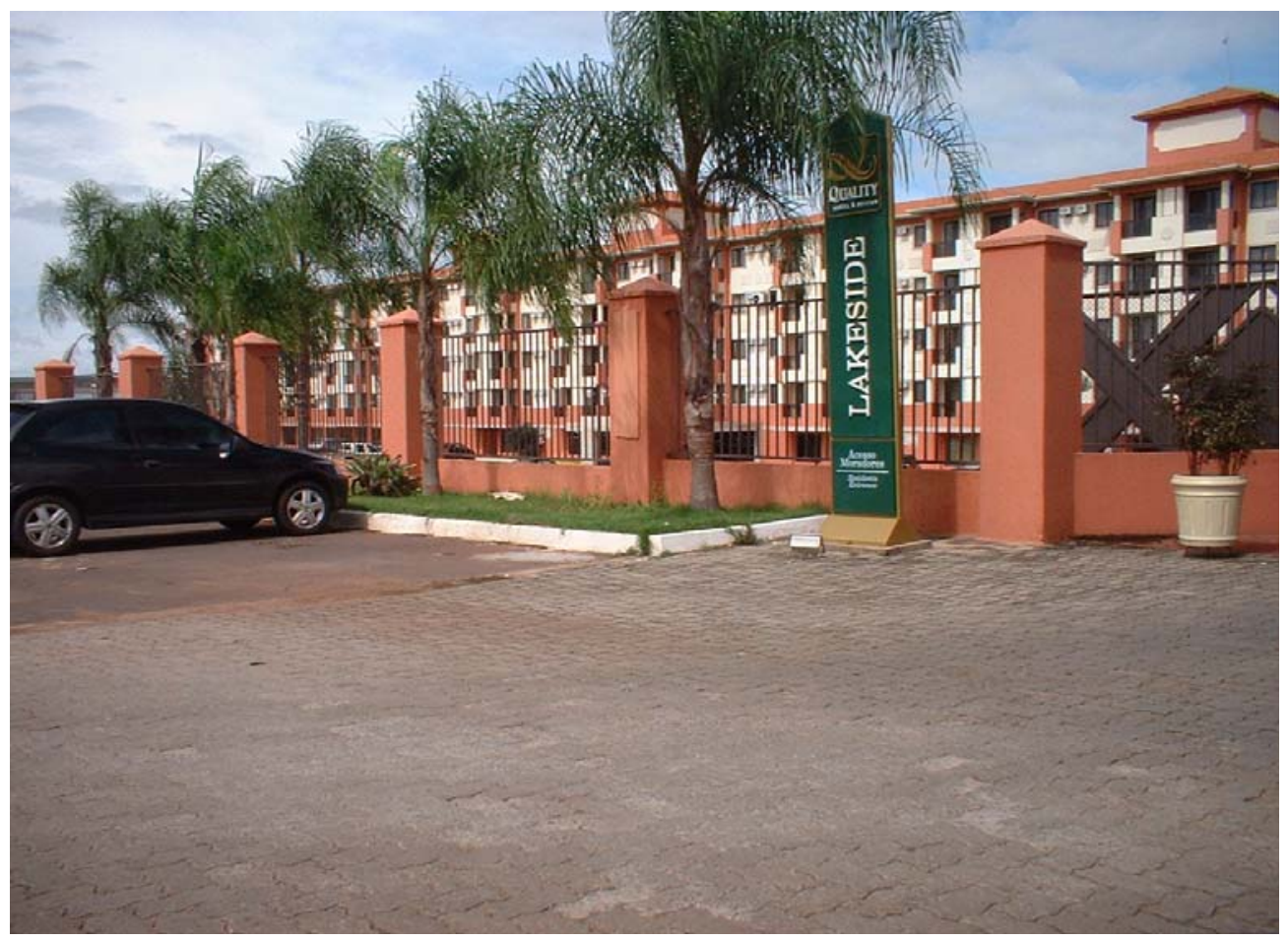

Ponte JK

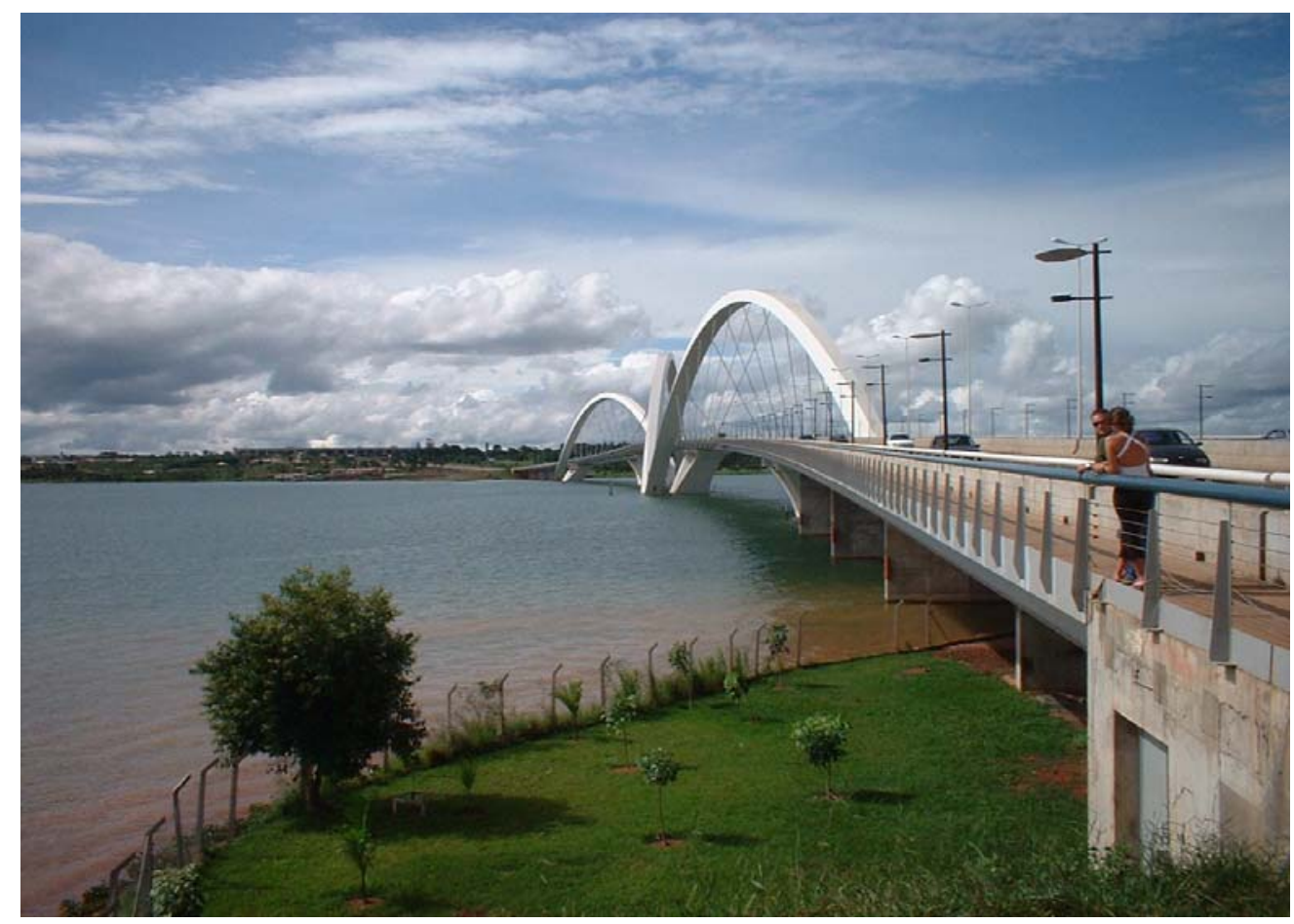


Portão Estilo Romano do Pólo 11 - Pontão Sul

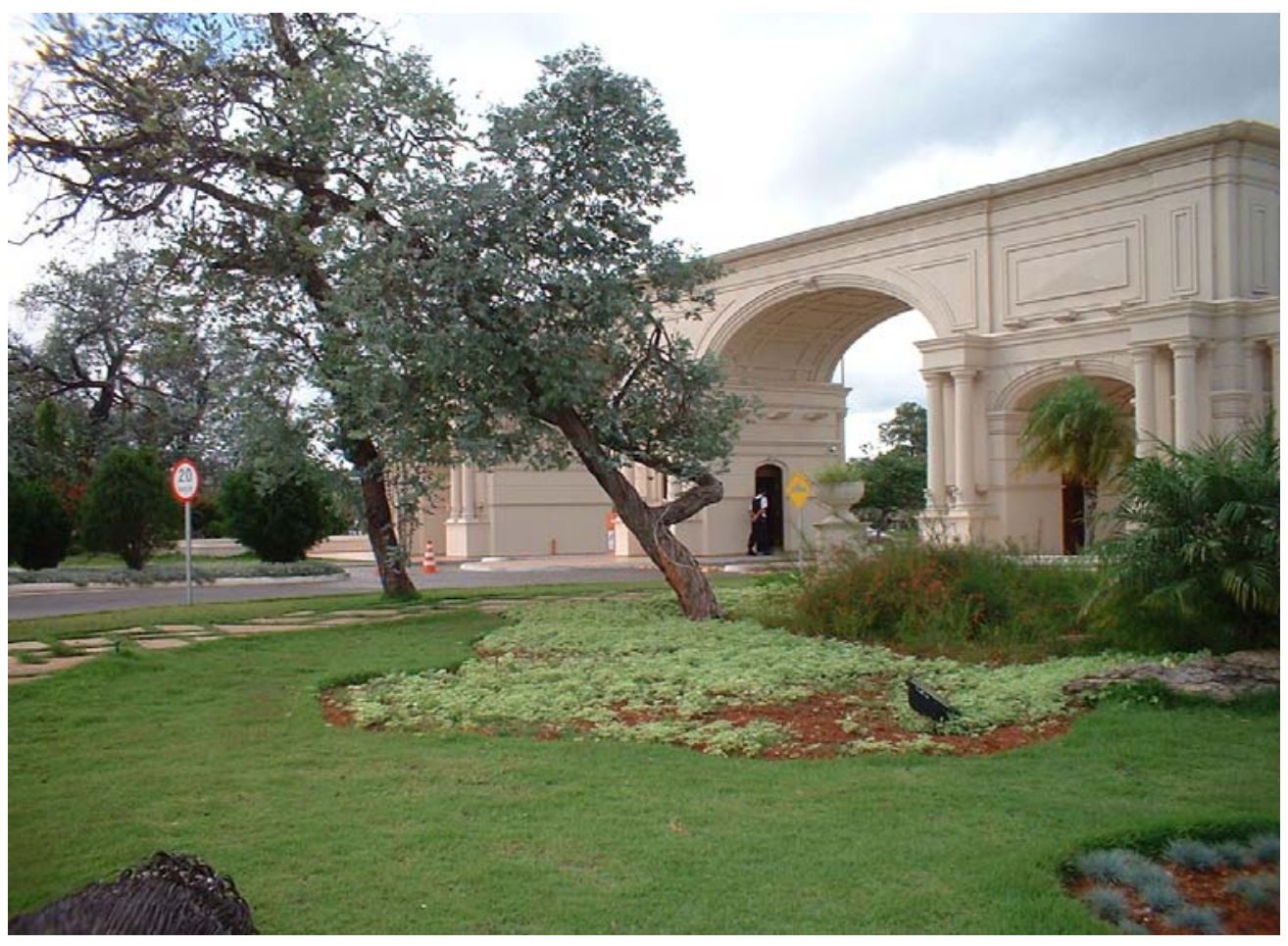

Surf Bar - Pontão Sul

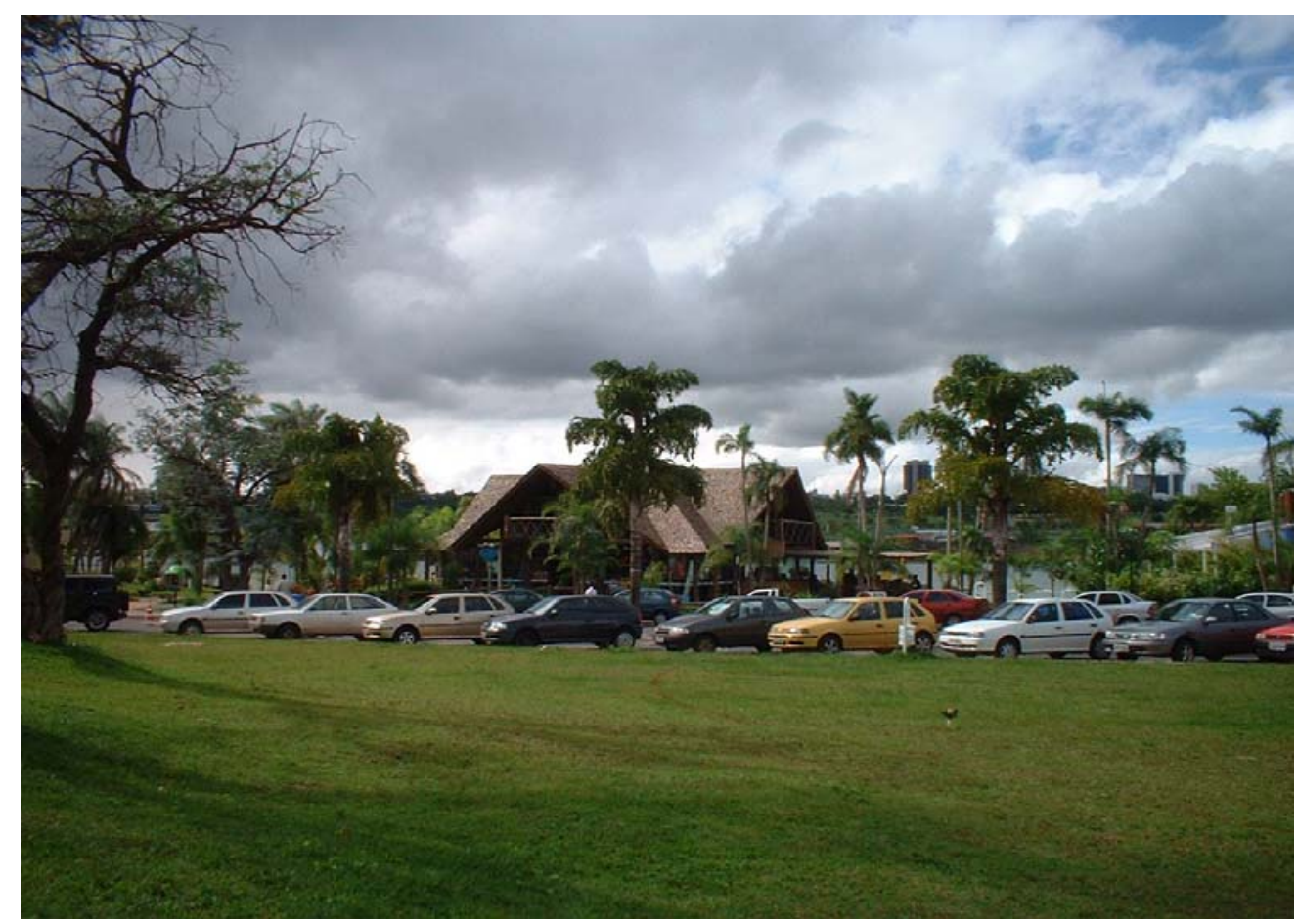


Prainha - Visão a partir do interior do Pontão Sul

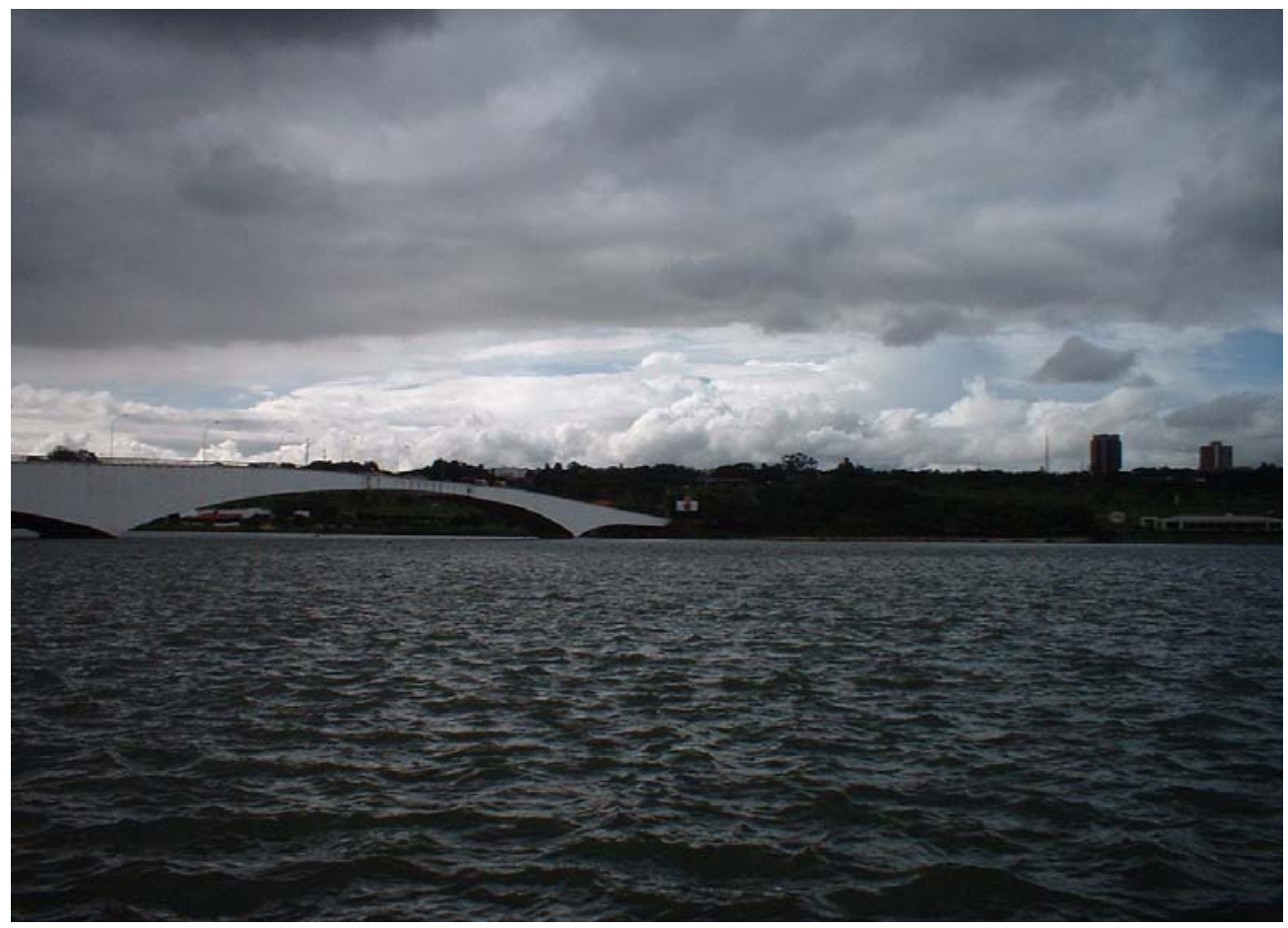

Píer 21 - Visão a partir do estacionamento localizado atrás do shopping

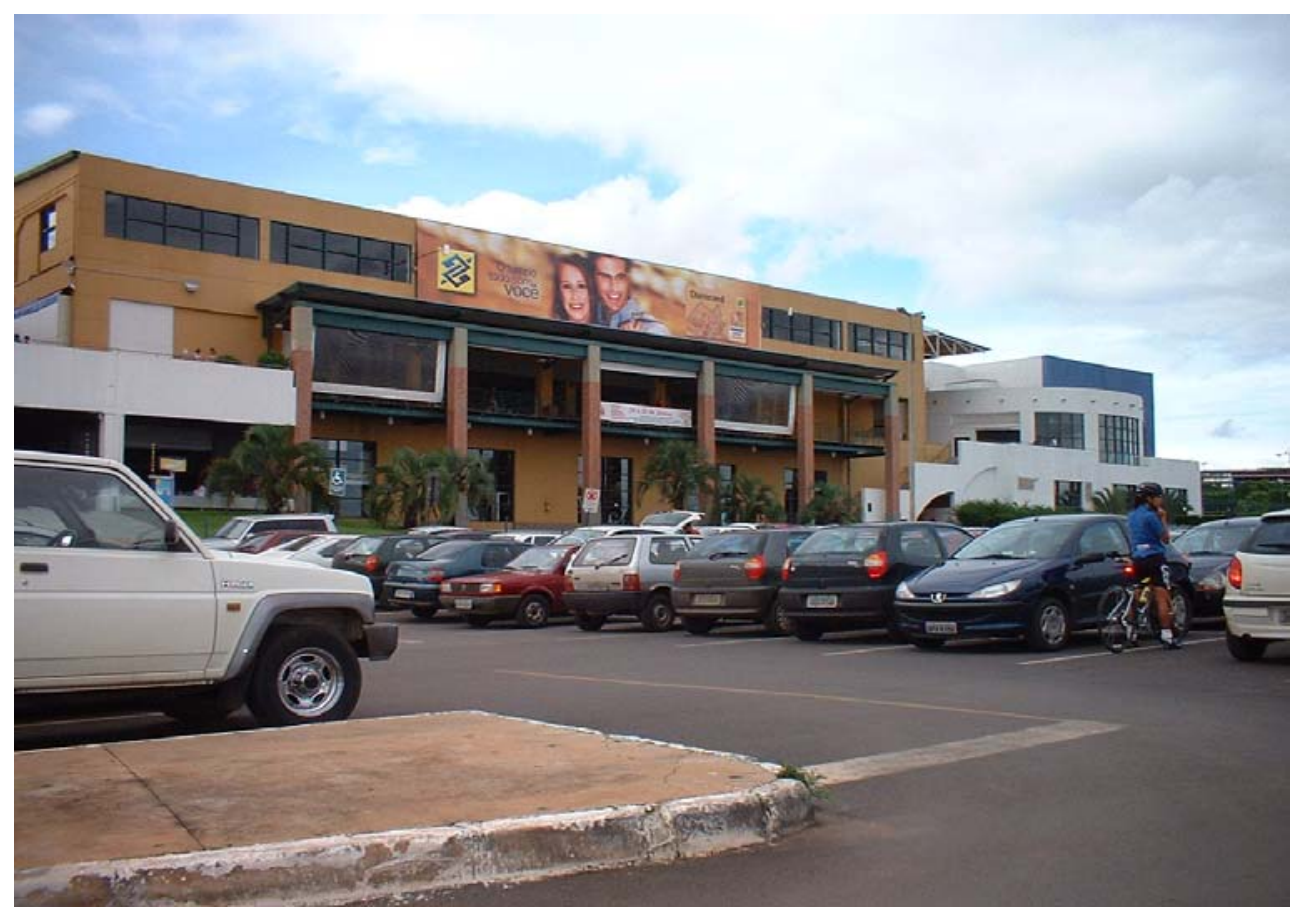




\section{Balneabilidade do Lago Paranoá}

Período de Amostragem: 15 de Abril a 13 de Maio de 2002

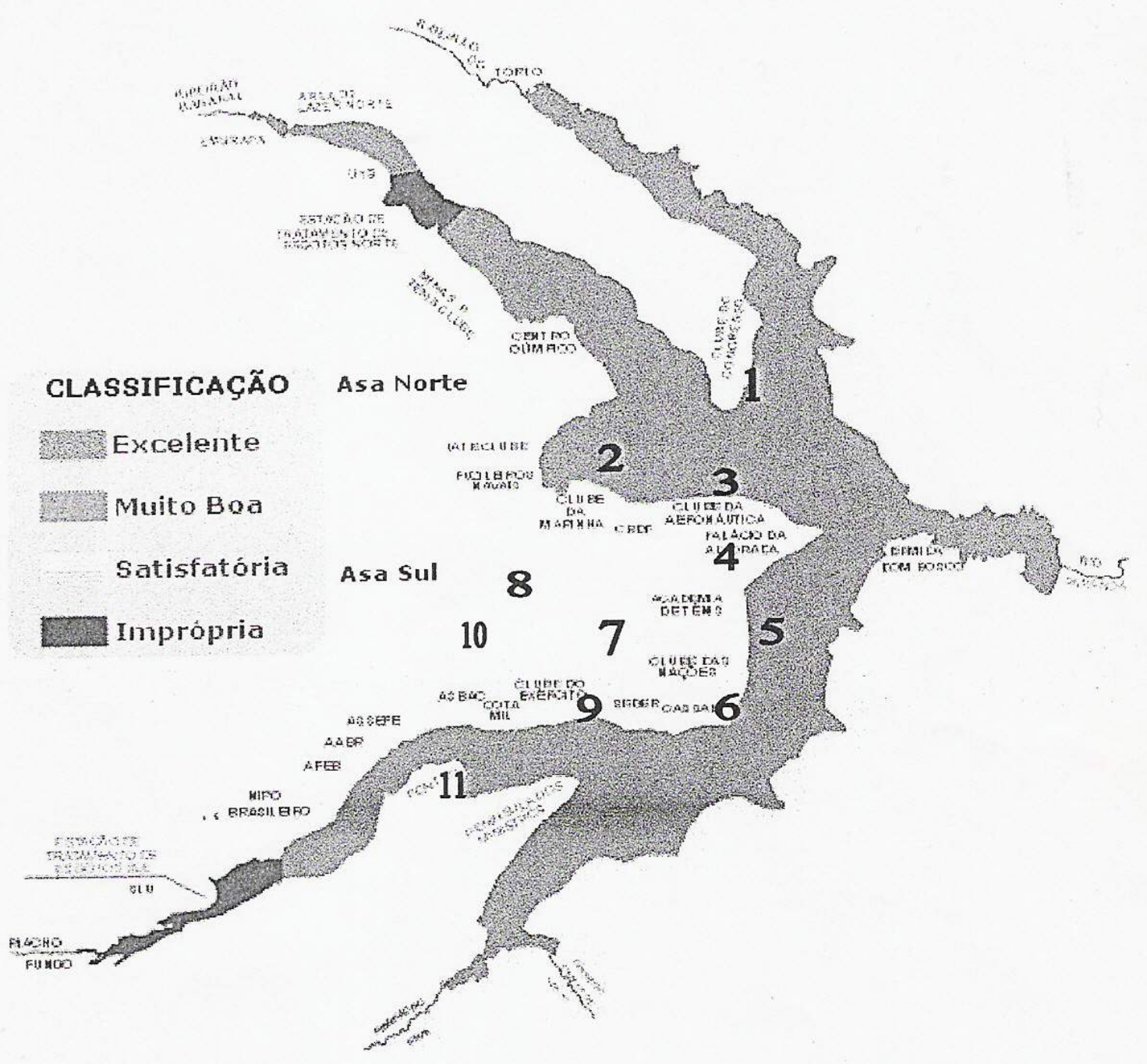

Por medida de segurança, as áreas próximas aos lançamentos dos afluentes das Estação de Tratamento de Esgotos-ETEs são permanentemente impróprias (Resolução n 020 CONAMA, 1986 - Art. 26 letra d, incisos 3 e 4.CAESB / SPHI / DRSA

1. PÓLO - PONTÃO LAGO NORTE

3. PÓLO - COMPLEXO BRASÍLIA PÁLACE

5. PÓLO - MARINA DO PARANOÁ

7. PÓLO - PARQUE TECNOLÓGICO

9. PÓLO - PARQUE AQUÁTICO

11. PÓLO - PONTÃO DO LAGO SUL
2. PÓLO - COMPLEXO DA ENSEADA

4. PÓLO - PARQUE DO CERRADO

6. PÓLO - CENTRO LAZER BEIRA-LAGO

8. PÓLO - CENTRO INTERNACIONAL

10. PÓLO - PRAÇA DAS NAÇÕES 


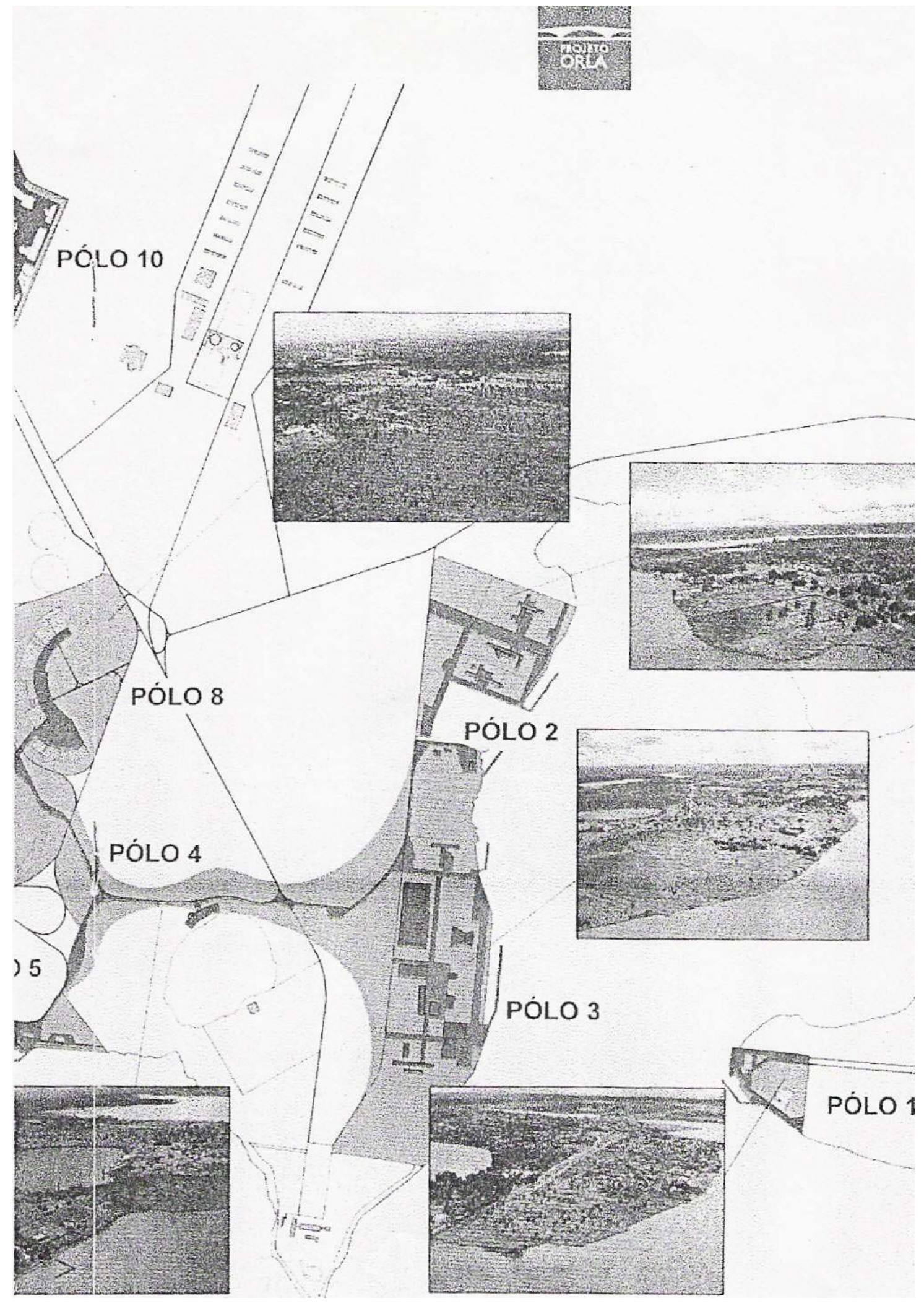




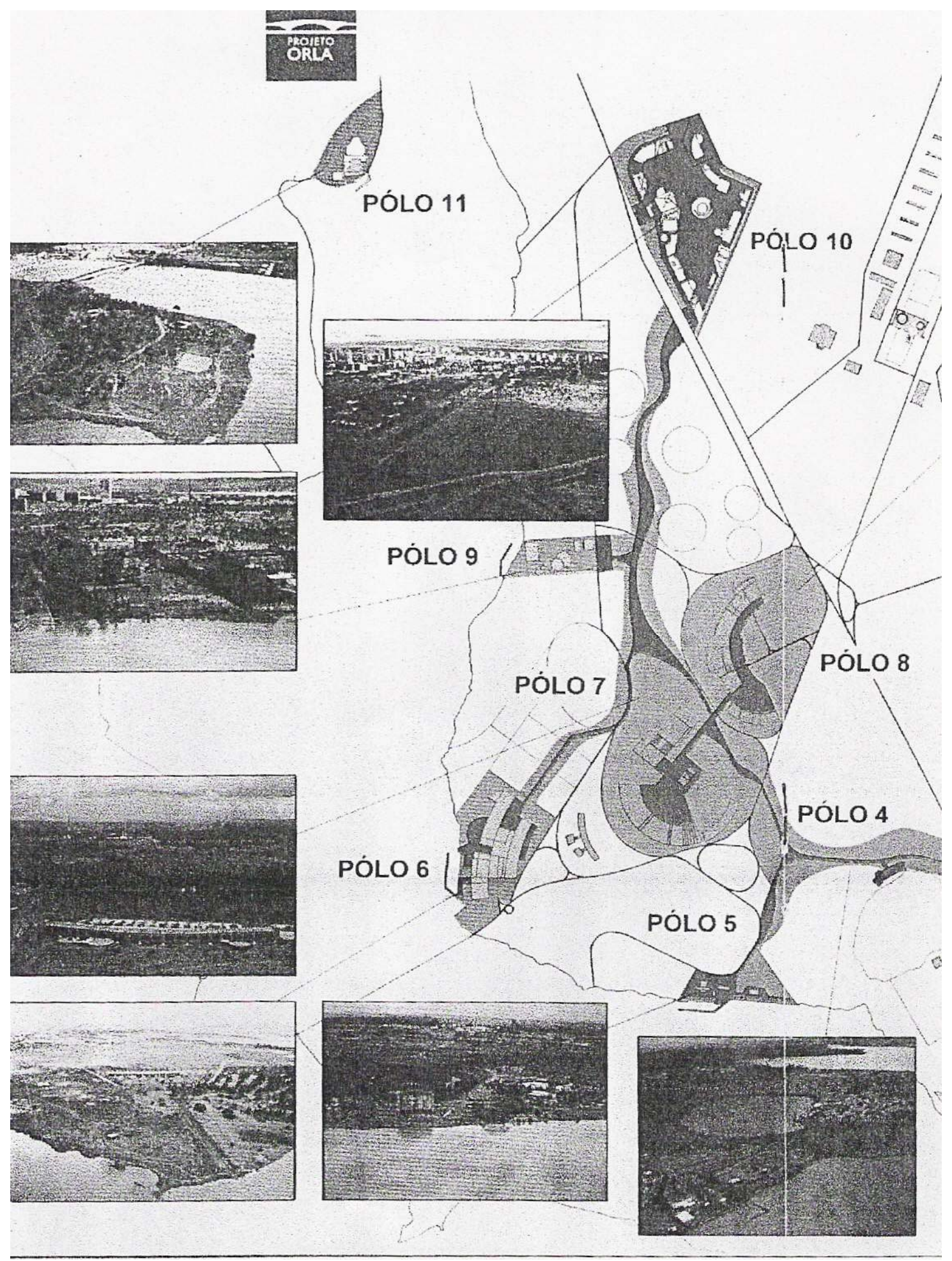




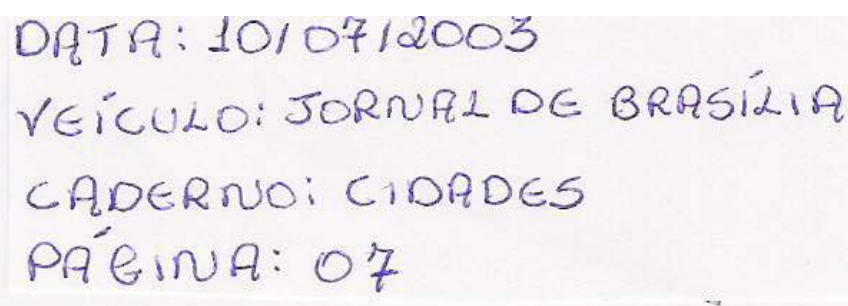

\section{Projeto Orla reformado}

A concha acústica e o pólo três do Projeto Orla estão sendo reformados e devem ser entregues à população ainda este mês, num investimento de $R \$ 1$ milhão. As obras estão em ritmo acelerado e deve ser aberta licitação para a exploração dos dois espaços. A concha acústica tem capacidade para duas mil pessoas e o pólo três vai comportar uma série de bares e restaurantes, conforme o projeto inicial, que tinha sido abandonado.

Outra obra de recuperação a ser entregue nos próximos dias é a fonte luminosa da Torre de Televisão. Ainda este mês será aberta licitação para a recuperação das fontes loca- lizadas na Praça do Buriti.

As obras maiores que estão sendo tocadas vão demorar mais: o Centrỡ de Convenções deve ser entregue ainda este ano e a Biblioteca Nacional, na Esplanada dos Ministérios, só ficará pronta em 36 meses. Outra obra grande, que já teve iniciada a fase de topografia e terraplanagem, é o viaduto da Rodoferroviária, que deve desafogar o trânsito entre o Eixo Monumental e a Estrada Parque Indústria e Abastecimento (EPIA).

Ainda neste mês de julho será licitada a construção do Museu Nacional projetado por Oscar Niemeyer, obra prevista para 36 meses. 


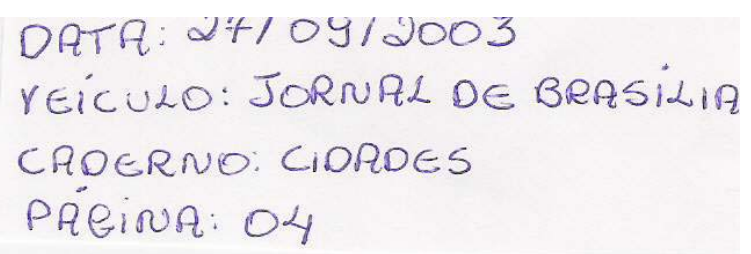

PROJETO ORLA

\section{Reforma da Concha Acústica fica pronta}

A revitalização do Projeto Orla ganhou, ontem, mais duas obras de lazer e cultura. governador Joaquim Roriz entregou a reforma completa da Concha Acústiea e dos quiosques do Pólo 3 do projeto, as margens do Lago Paranoá. A revitalização, explicou Roriz, é uma das ações para consolidar a vocação turística do Distrito Federal e ampliar - lazer para a sua população.

"O Projeto Orla reaproxima a cidade do Lago. Além de devolver o Lago à população, permitindo melhor uso e o acesso a todos, criando um espaço atrativo tambem para 0 turista", ressaltou governador, que participou da solenidade acompanhado dos secretários David de Matos (InfraEstrutura e Obras), Pedro Bório (Cultura) e Genésio Tolentino (Agência de Infra-Estrutura e Desenvolvimento Urbano).

O governo viu no Projeto Orla e na urbanização do Lago Paranoá, cartão-postal da cidade, a grande cartada para oferecer mais lazer e cultura aos brasilienses. Ao redor, já existem bares, restaurantes, casas de shows, marinas, centros comerciais e hotéis.
Para resgatar a Concha Acústica, de acordo com o secretário David de Matos, foram executados vários serviços, como a recuperação de camarins, sanitarios, bilheteria e cabina de som, além da recuperação completa de toda a rede elétrica e hidráulica. Os trabalhos de limpeza do piso e pintura dos bancos foram realizados pela Novacap. O custo da obra foi de $R \$ 230$ mil.

Durante a solenidade, índios das tribos Xavante e Karajá fizeram apresentação de canto e dança ritual, dentro do projeto Rito de Passagem, do Instituto de Desenvolvimento das Tradições Indígenas.

A Concha Acústica de Brasília é um anfiteatro destinado a realizações e apresentações teatrais, shows e espetáculos ao ar livre, de viva voz, sem necessidade de ampliação eletrônica de som. O anfiteatro tem capacidade para abrigar seis mil pessoas sentadas, numa área construída de 8.435 metros quadrados. 0 palco, em nível inferior, é dotado de concha acústica com 42 metros de comprimento e 5 metros de altura. 


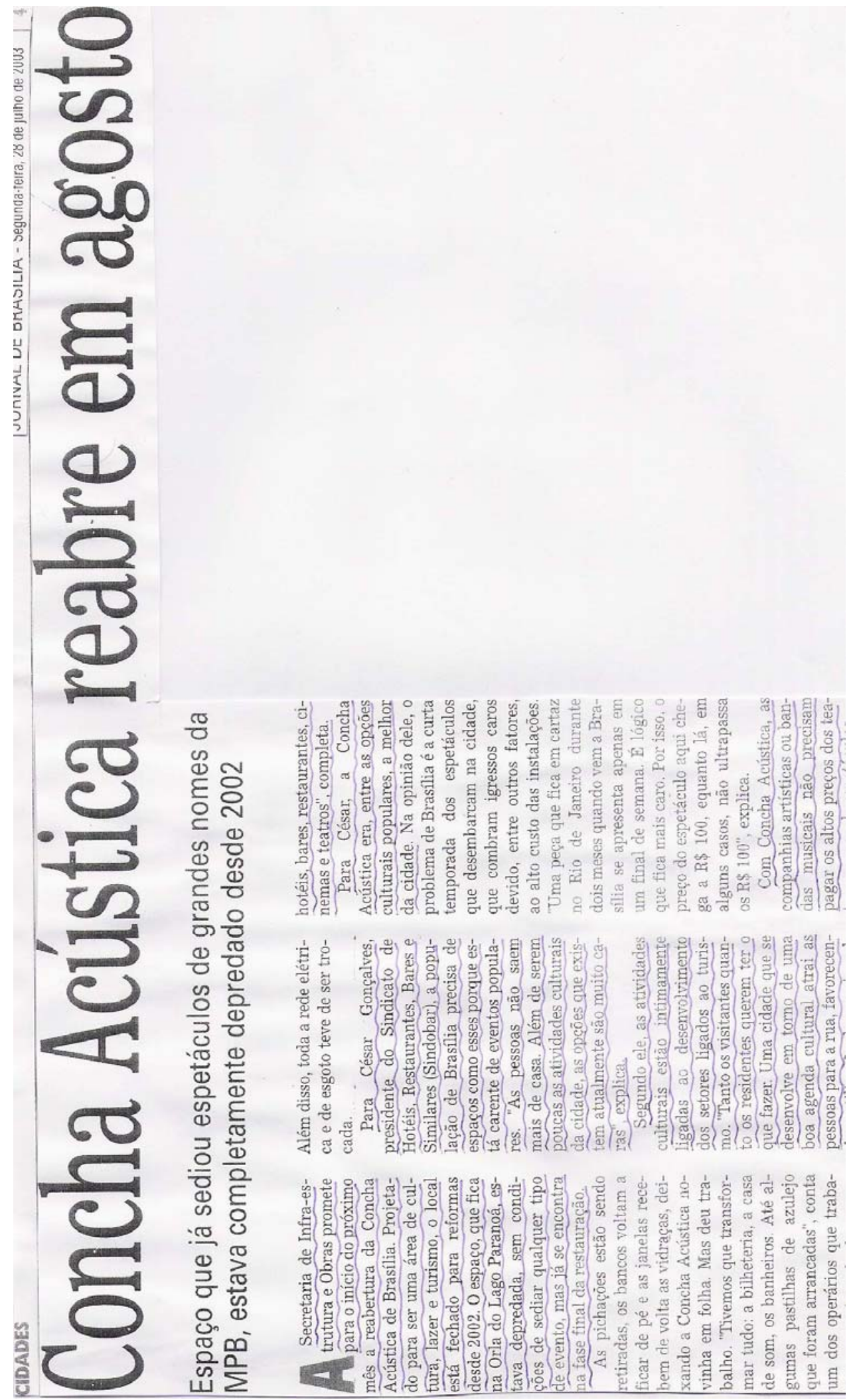


DATA: 28/07/2003

VEICULO: JORNAL DE BRASILIA

CADERNO: CIDADES

PABIINA: 04

\section{De Djavan a Roberto Carlos}

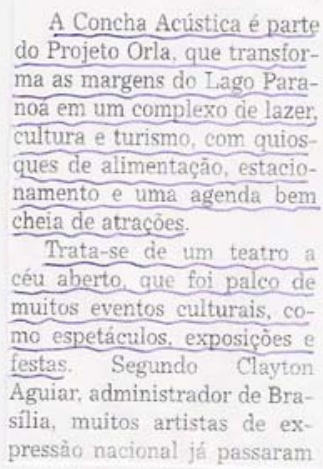

por lá. Lembro do Caetano Veloso, Djavan e Roberto Carlos, além de uma ediçâo do Concurso Miss Brasil, na década de 70", conte. Em 1996 , a banda brasiliense Nativus fer um grande show de lancamento do seu primeiro $C D$ na Concha Acústica. Em 1999, o festival de música Porão do Rock também foi realizado no espaço.

Rodrigo Rollemberg, que em 1995 era deputado distrital pelo PSB, conta que, na época, apresentou na Camara
Legislativa uma proposta de emenda ao orcamento do GDF destinando recursos para a recuperação da Concha, que, coliela altura, já nẽo tinha condicões die use. Èm 1006 . quando foi secretario de Thifismo, a Concha foi reaberta. om a retomada do Projeto Orla depois de ums restaura çâo. "Era uma das methores opçōes de entretenimento em Brasilia. É uma pena que tepha sido fechada de novo. Th. mara que seja uma reforma râpida", diz ele, otimista 


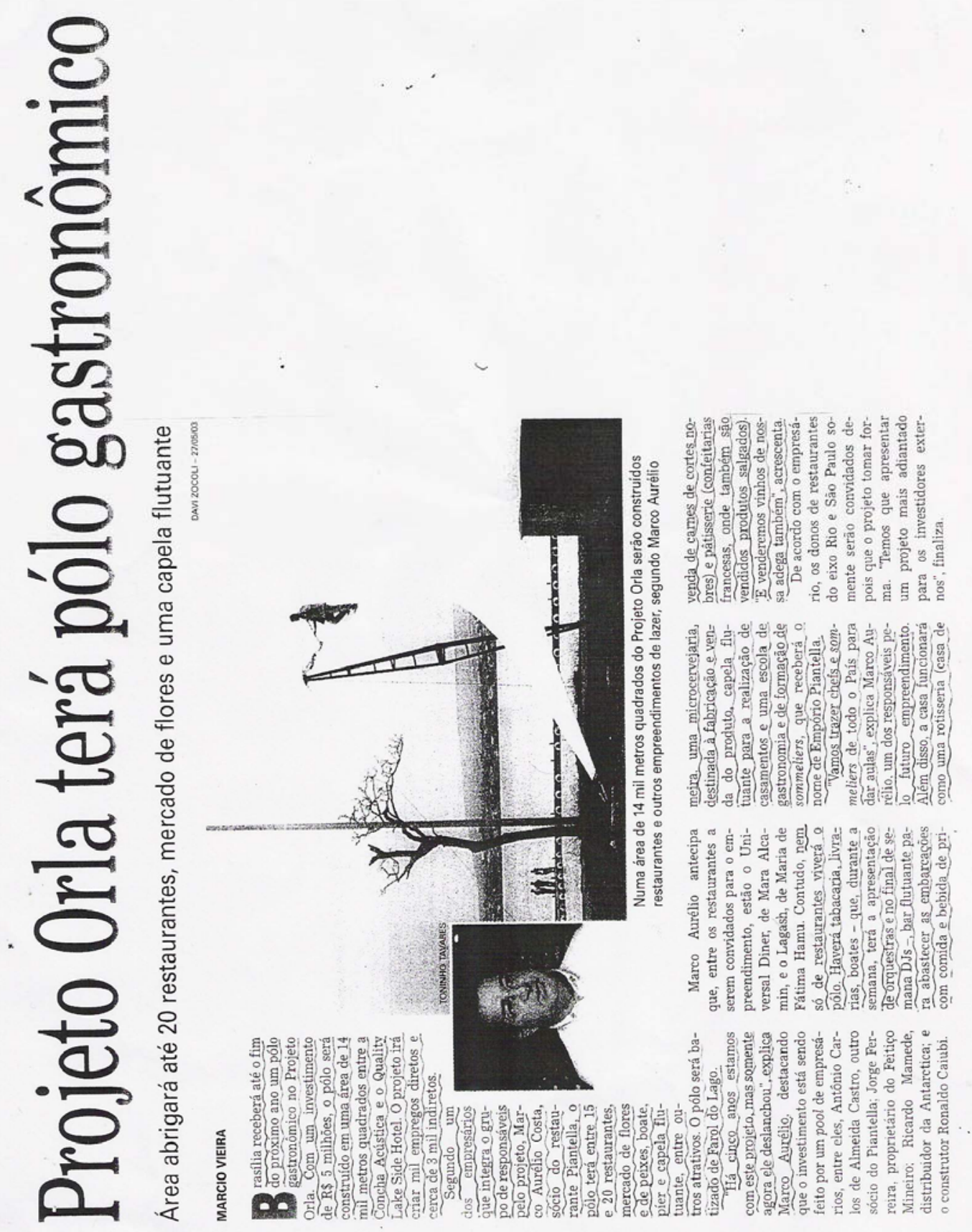




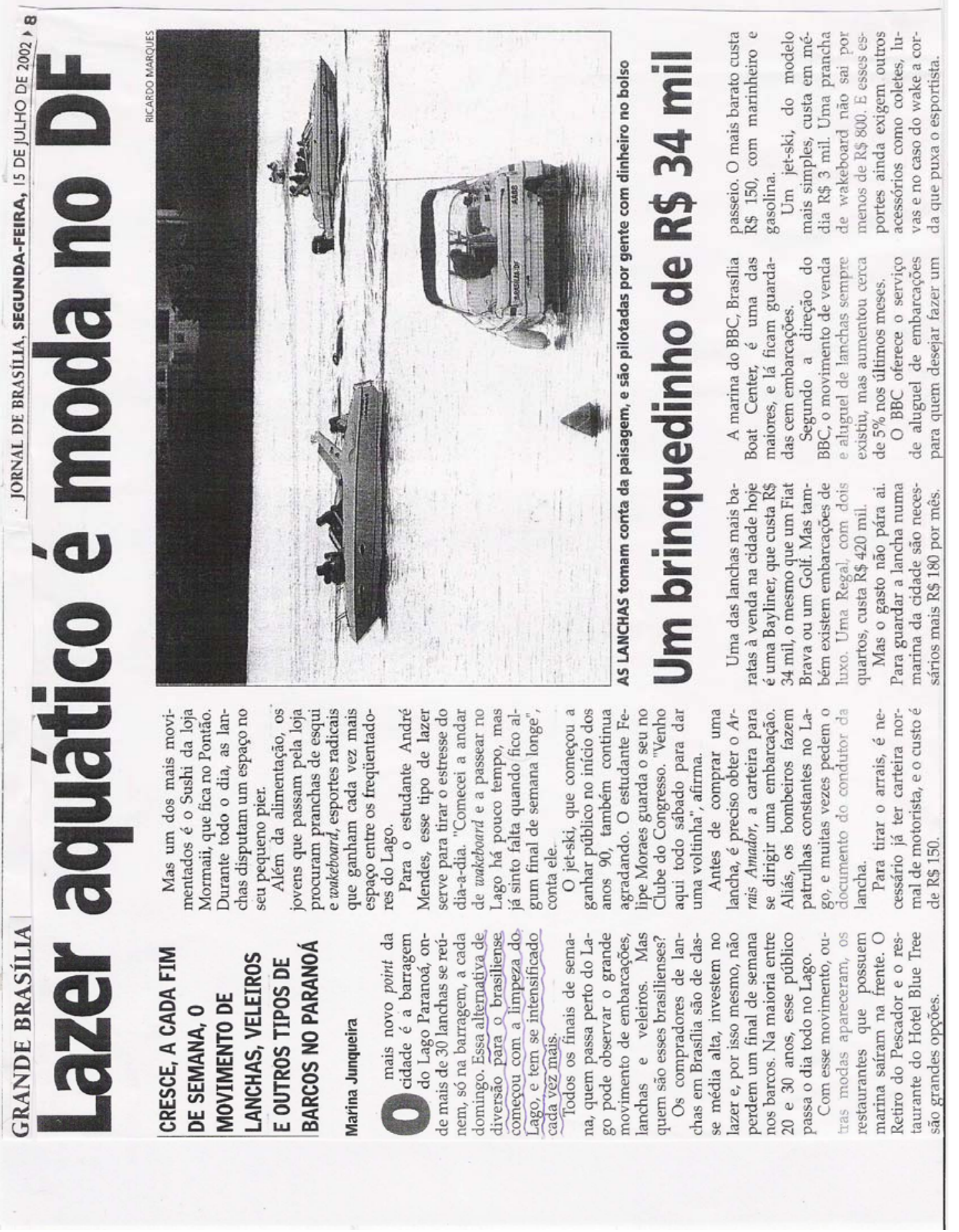




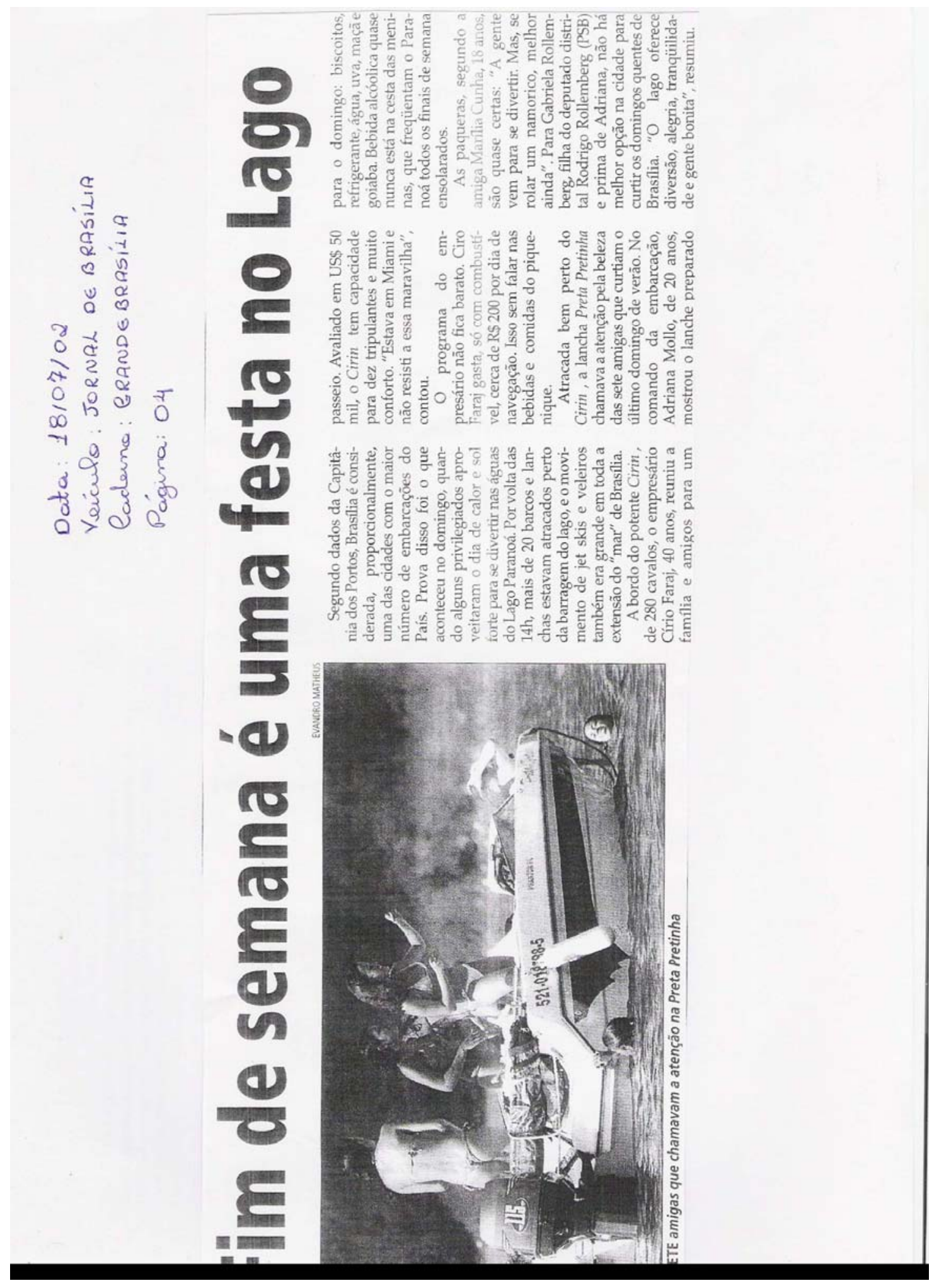




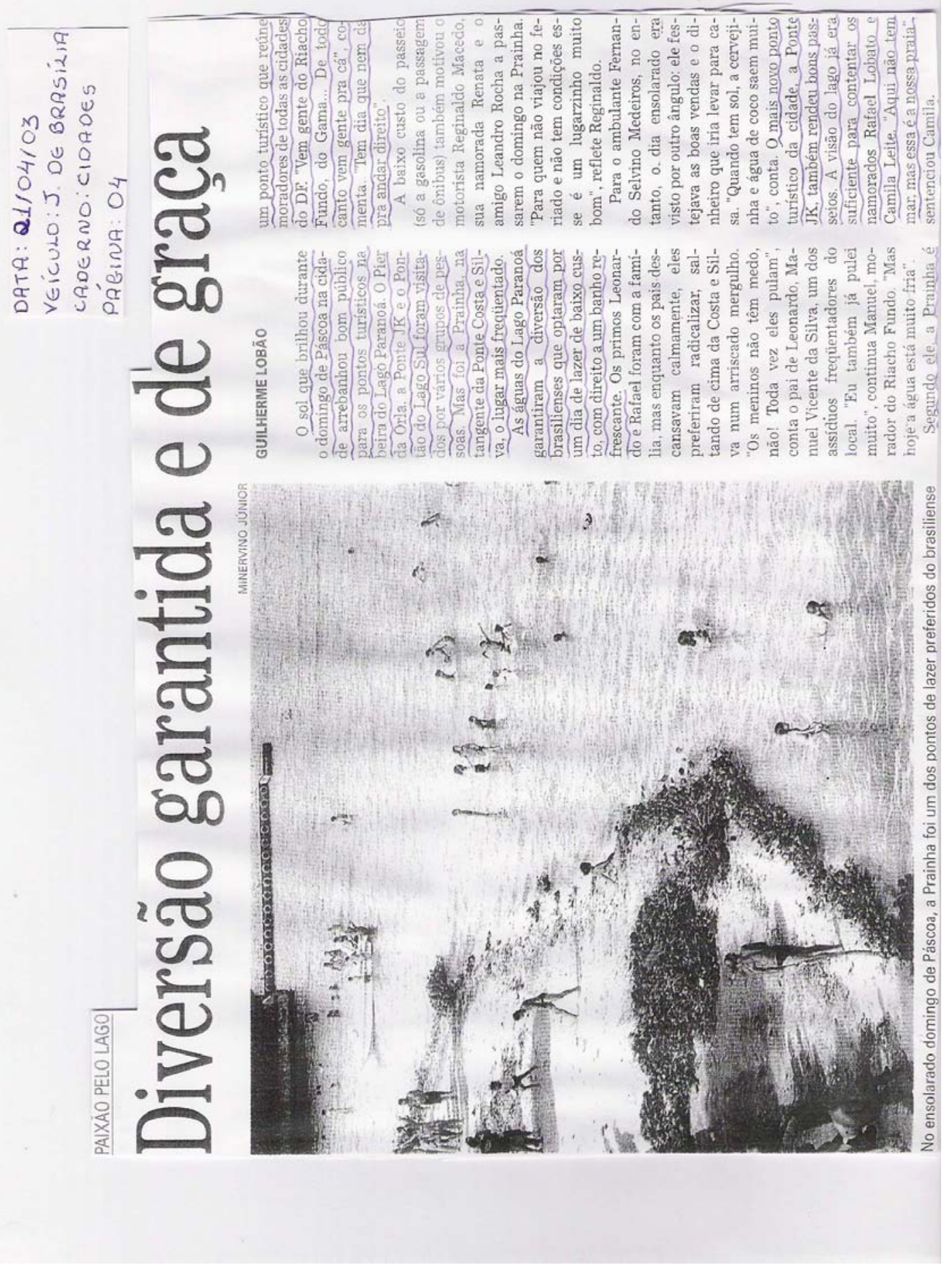




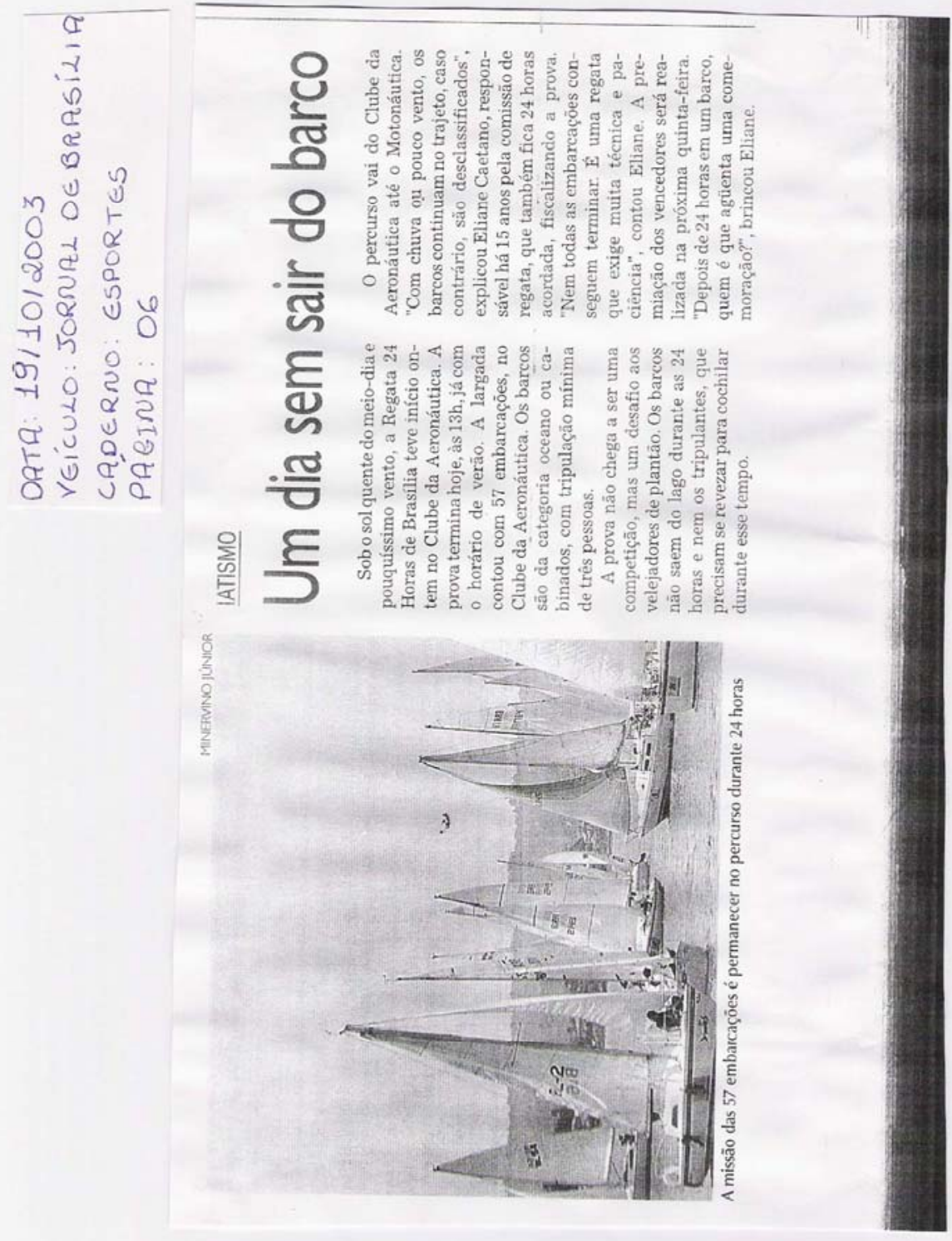




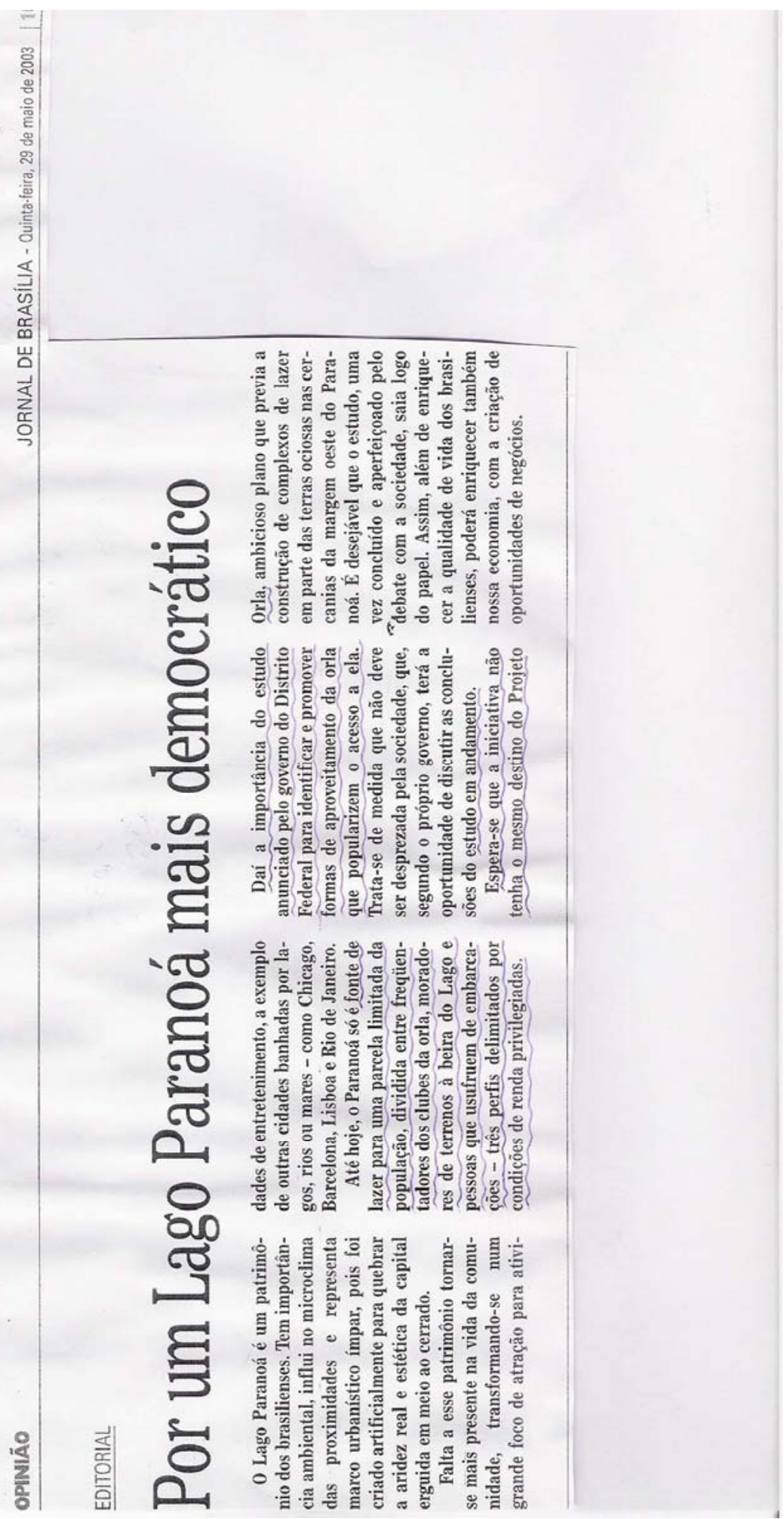



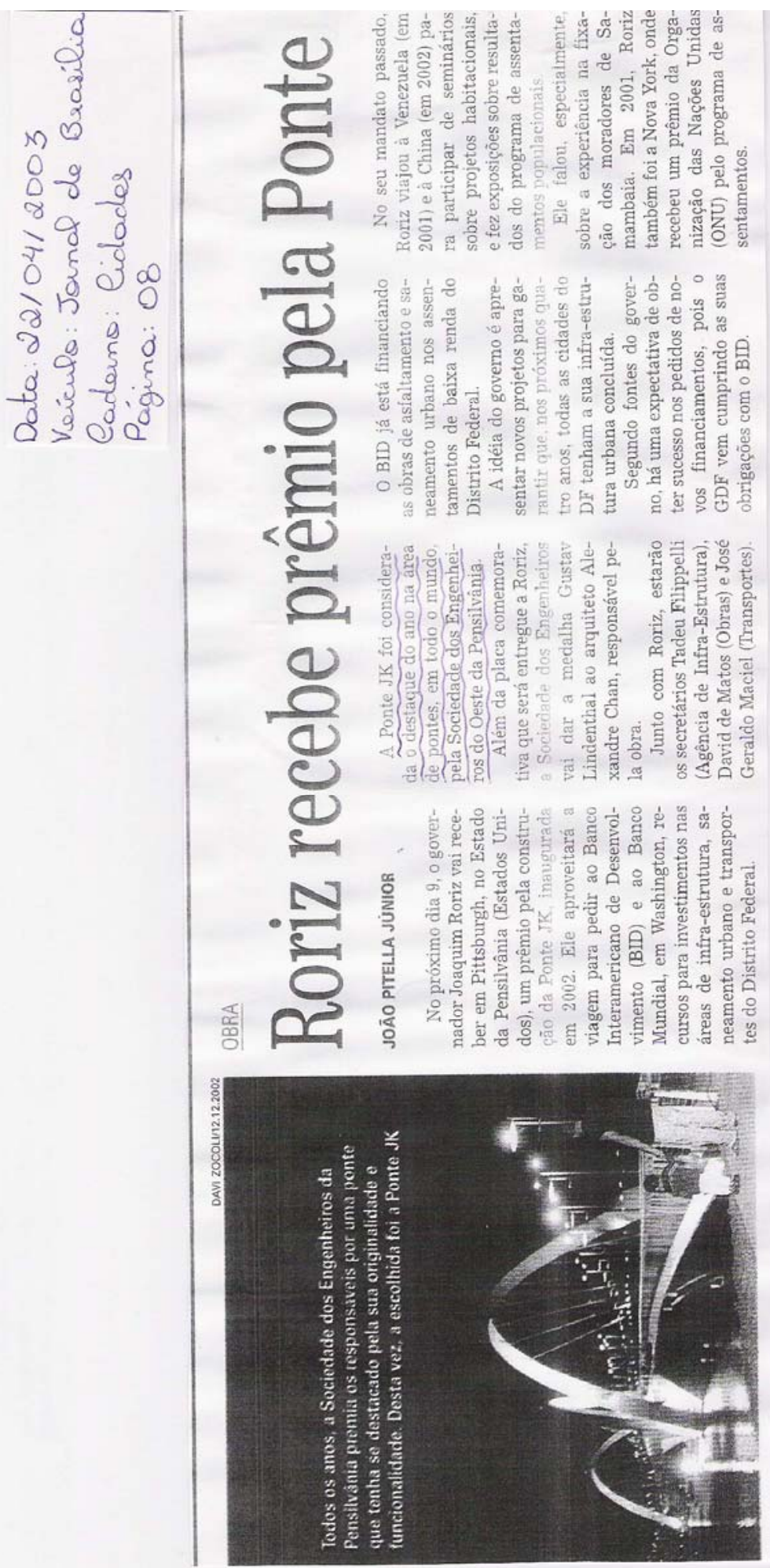


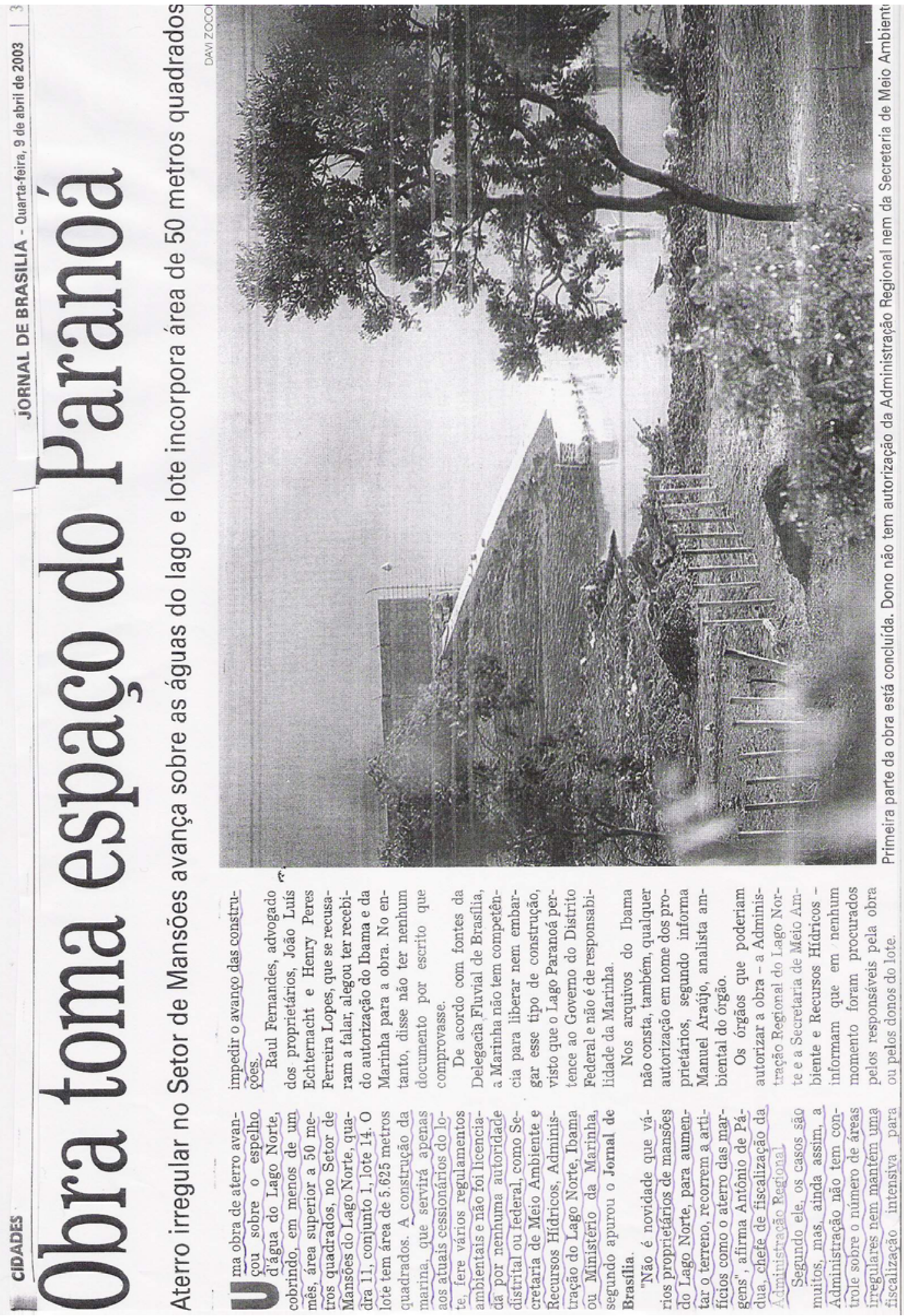



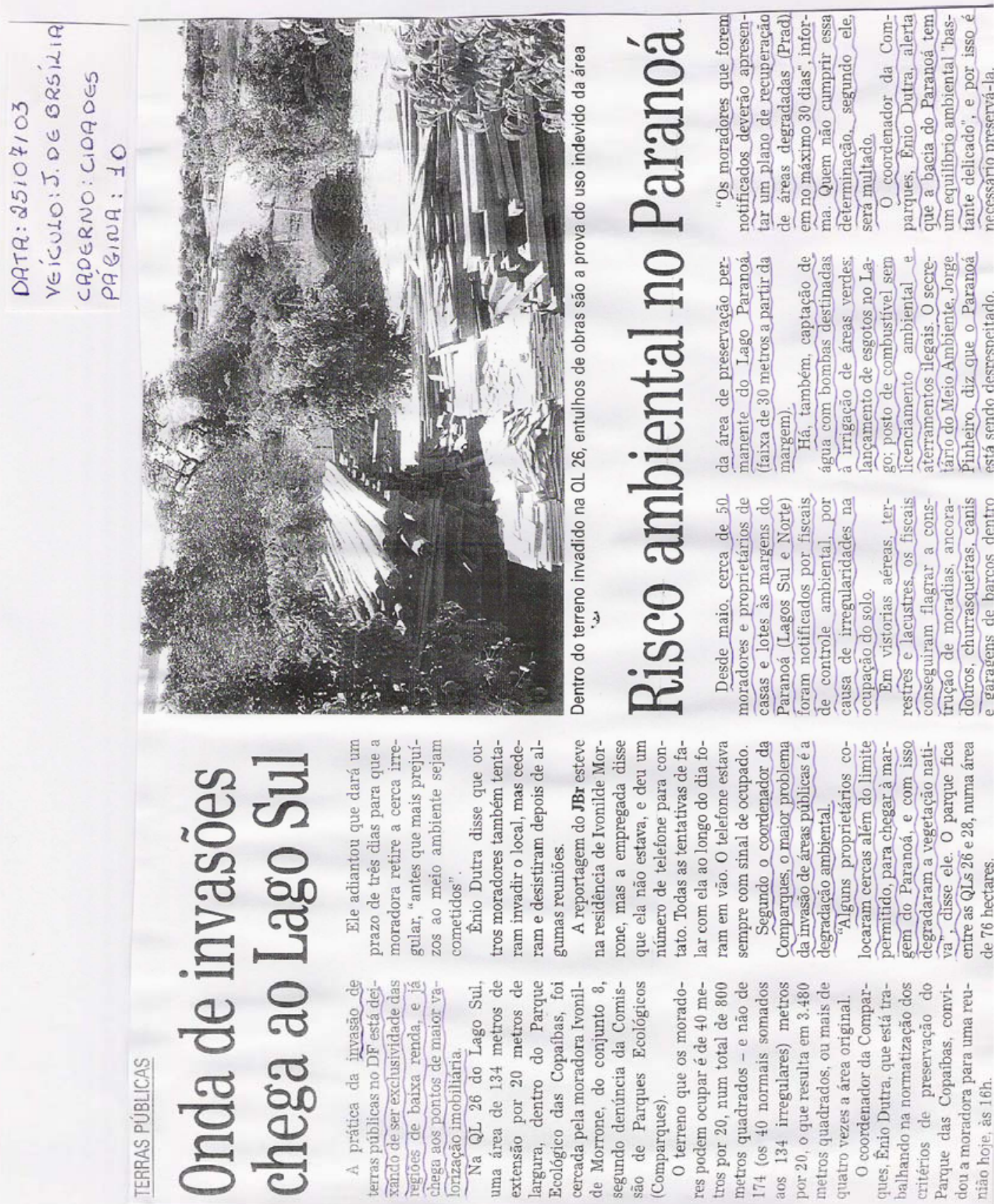


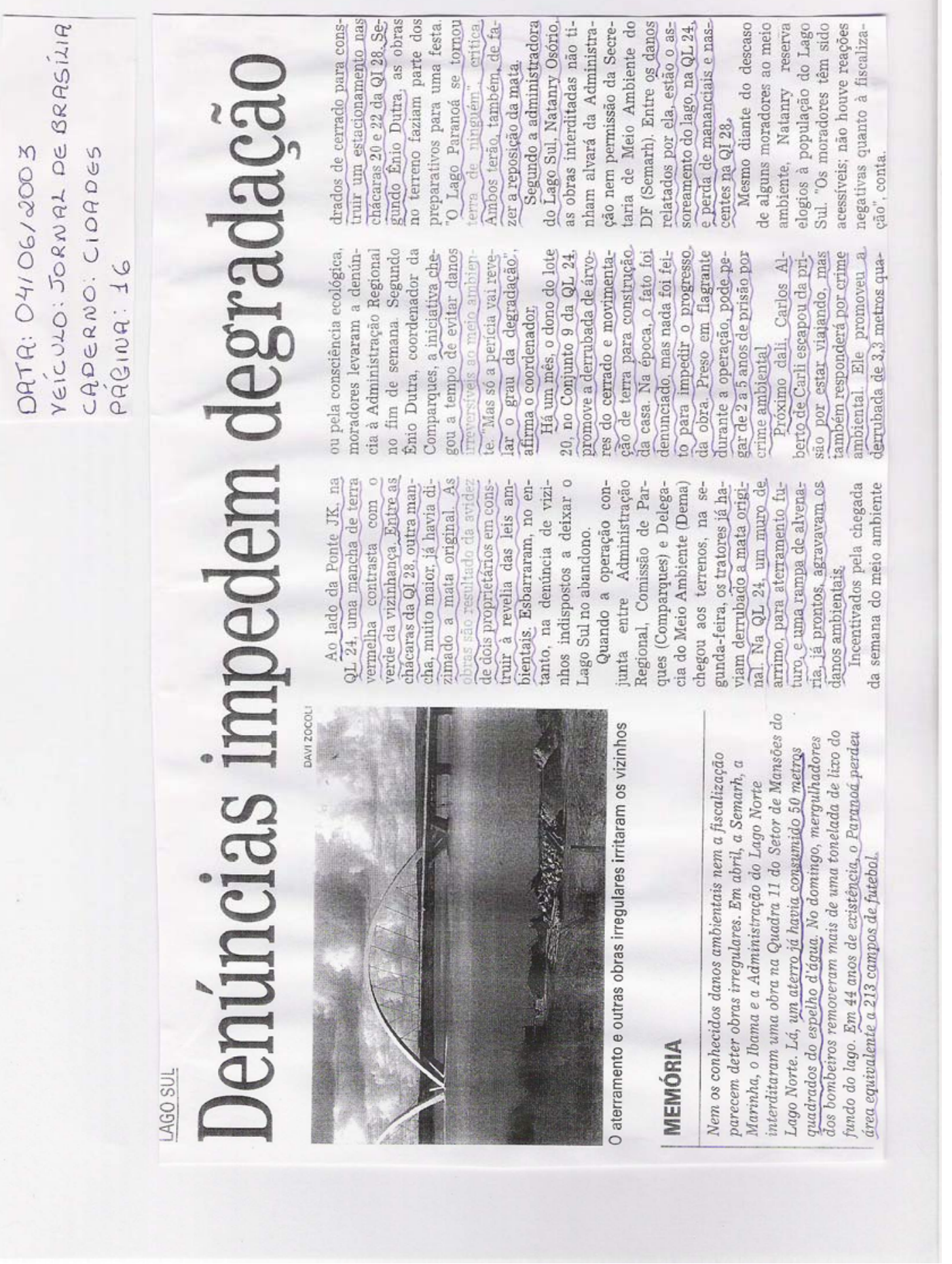


DATR: 09/04/2003

YEÍCULO: JORNAL DE BRASILIA

CADERNO: CIDADES

PŔGINA: 03

\section{Área está sob proteção}

Mesmo que os proprietários do terreno tivessem recorrido à Administracâo Regio-

nal ou à Secretaria de Meio

Ambiente, provavelmente o pedido teria sido negado. Isso porque o Lago Paranoá é área

de preservacâe permanentes protegida pelo artigo $3^{\circ}$ do Código Florestal

o código só permite a su-

pressão total ou parcial de flo-

restas ou outros tipos de vege-

taçāo de preservação perma-

nente com previa autorizaçáo

To Poder Executivo Federal, e

somente quando é necessária à

execução de obras, planos, ati-

idades ou projetos de utilida-

de pública ou interesse social.

0 aterro que está sendo

construido no lote 14, no Setor de Mansoes do Lago Nor-

ấn atende aos rectinisitos

đo refericio artigo: não visa ao

interesse social nem é de utili-

dade pública. Atende, apenas,

a interesses particulares. 

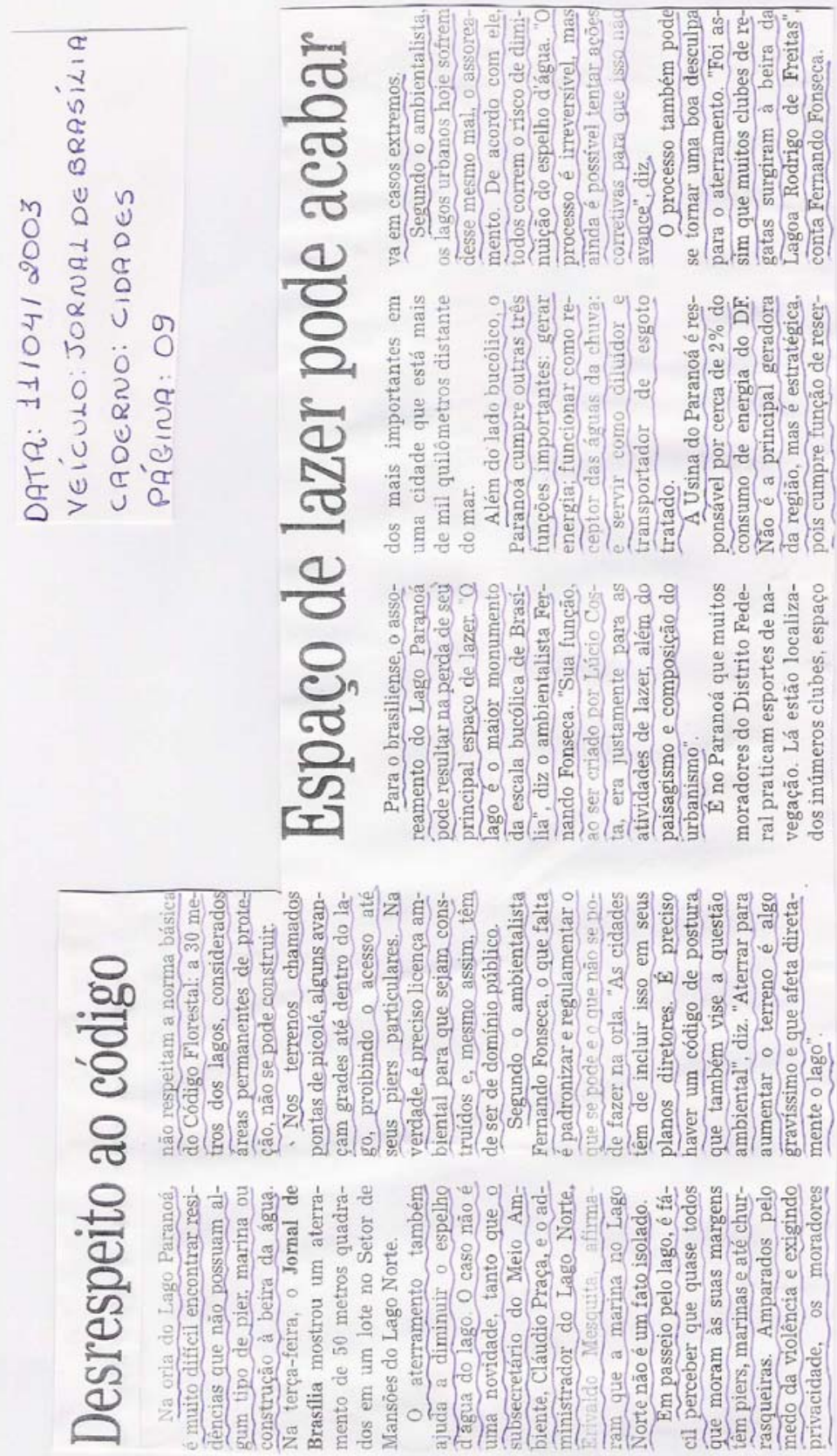


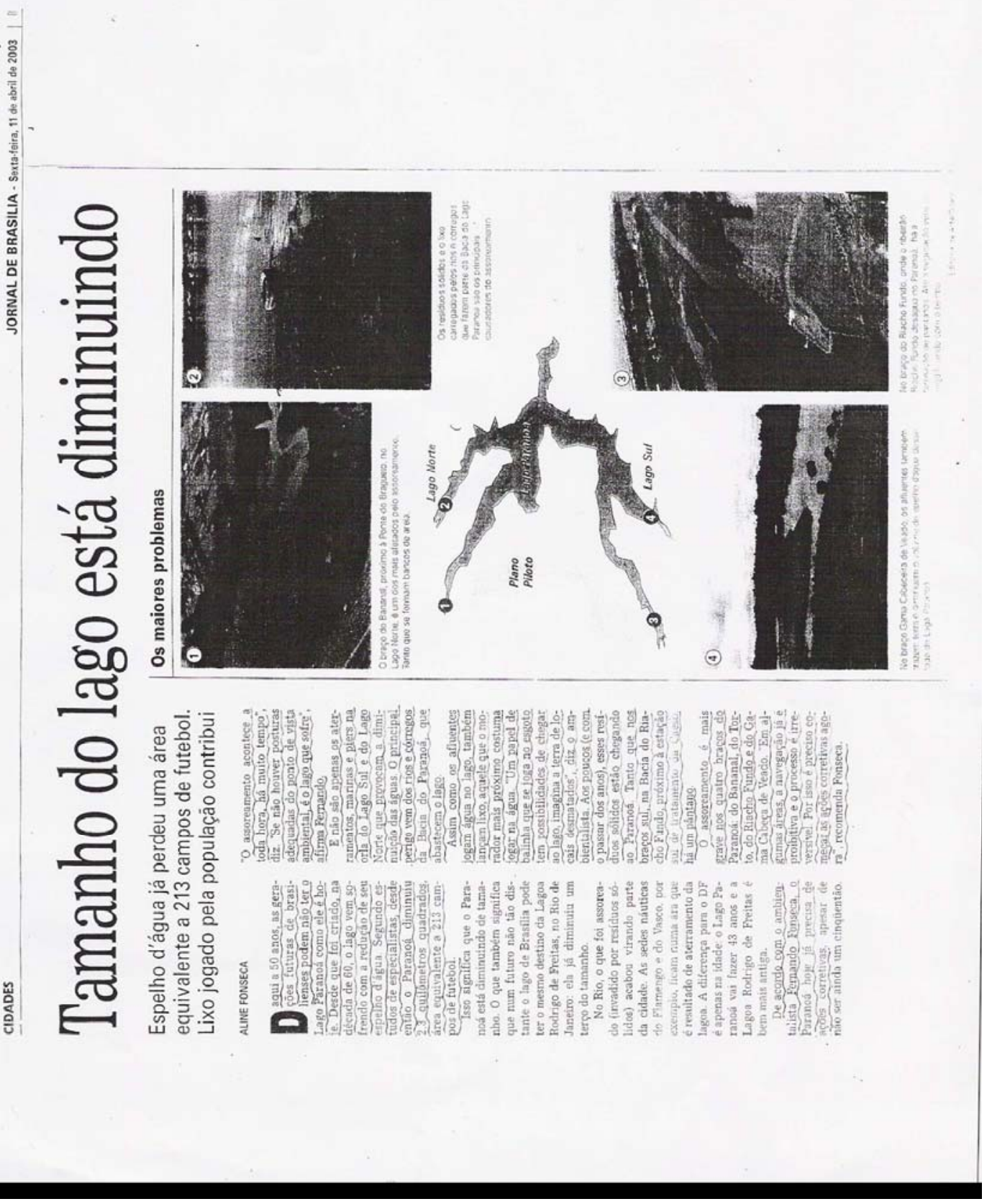


DATA: 08/08/03

YEÍCULO: JORNAL DE BRASILIR

CADERNO: CIDRDES

PREIINA: 03

\section{Prejuízo para o Paranoá}

De forma isolada, a morte renos, a água do córrego é rado Córrego Vereda da Cruz é ruim para os moradores locais muito pior para o Lago $\mathrm{Pa}$ ranoá, fonte de lazer do brasi-

liense e também de umidade para o Distrito Federal.

$\mathrm{Na}$ cadeia ambiental, problema no Vereda é um dos responsáveis pelo assoreamento (carregamento de resíduos Solidos para o leito) do Lago Paranoá. O córrego desemboca no Vicente Pires, afluente do Riacho Fundo, que por sua vez. forma um dos quatro braços do Paranoá.

O braco do Riacho Funde está em estado crítico. Hoje, a profundidade do lugar não chega a um metro, por causa ao assoreamento, E a falta do curso do Vereda da Cruz piora a situação, pois é menos volume de água chegando ao lago. Próximo às chácaras no Park Way que ainda mantêm a característica rural dos terra. Três bocas-de-lobo com aproximadamente dois metros de diâmetro, construídas para aguentar o volume de água do Vereda da Cruz e das chuvas, são a prova de que o curso d'água está moribundo.

No local, um incêndio recente queimou a terra seca que substituiu a àgua. "Eu só entrei aqui uma vez, quando estavam construindo as bocas-de-lobo Agore secou disse 0 chacareiro Brauli Ferreira da Silva, morador há quase 20 anos da regiâo.

Segundo Paula Mochel. engenheira florestal do Ibama-DF, o dano ambiental provocou também um dano socioeconômico. "A morte do córrego vai afetar a vida da comunidade que dependia dele para a sobrevivência. Isso significa um prejuizo social e financeiro para essas pessoas", afirmou a engenheira. 


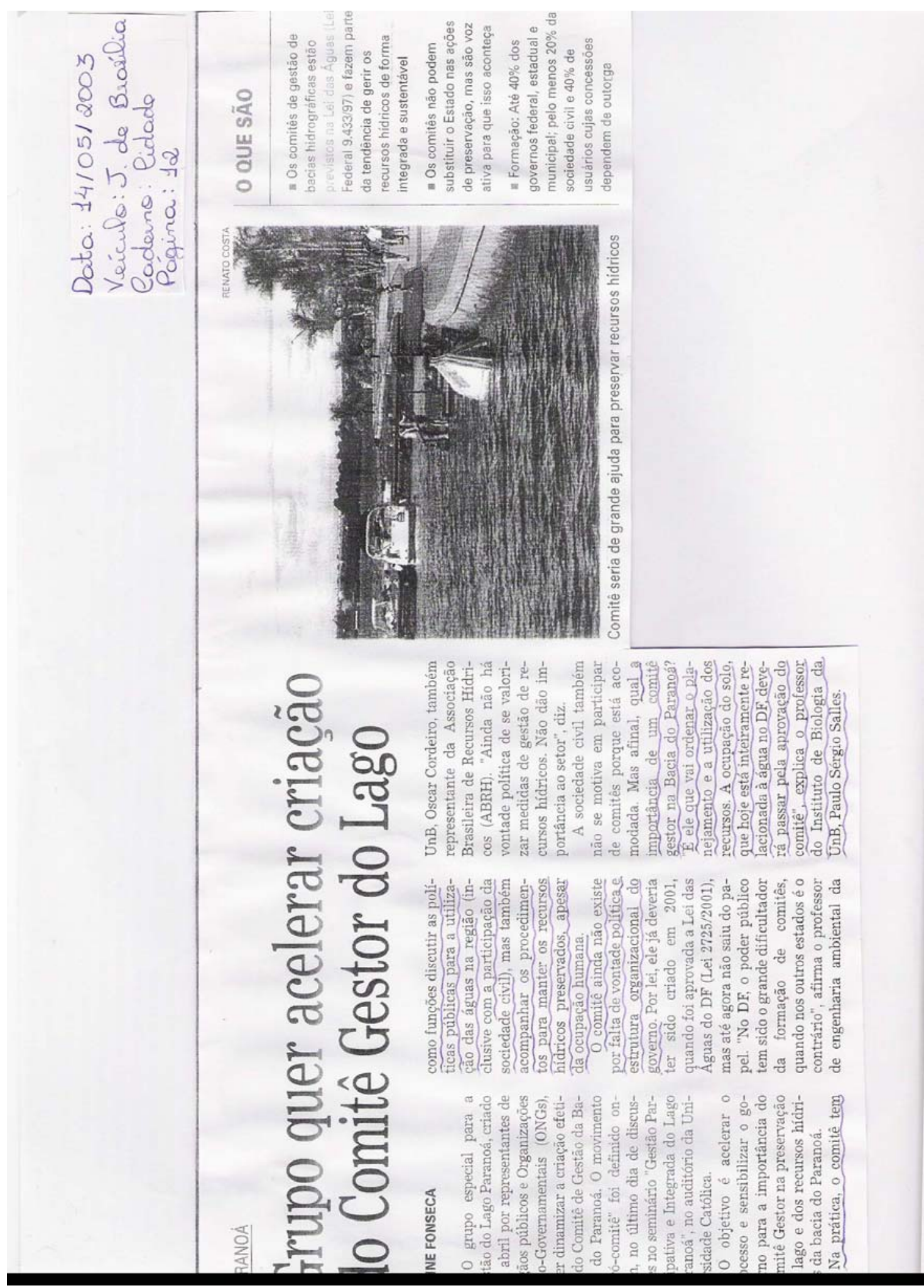

